Article

\title{
Chemical Eustress Elicits Tailored Responses and Enhances the Functional Quality of Novel Food Perilla frutescens
}

\author{
Youssef Rouphael ${ }^{1, *(\mathbb{D})}$, Marios C. Kyriacou ${ }^{2}$, Petronia Carillo ${ }^{3}{ }^{[}$, Fabiana Pizzolongo ${ }^{1}{ }^{1}$, \\ Raffaele Romano ${ }^{1}$ and Maria Isabella Sifola ${ }^{1}$ \\ 1 Department of Agricultural Sciences, University of Naples Federico II, 80055 Portici, Italy; \\ fabiana.pizzolongo@unina.it (F.P.); raffaele.romano@unina.it (R.R.); sifola@unina.it (M.I.S.) \\ 2 Department of Vegetable Crops, Agricultural Research Institute, Nicosia 1516, Cyprus; \\ m.kyriacou@ari.gov.cy \\ 3 Department of Environmental, Biological and Pharmaceutical Sciences and Technologies, \\ University of Campania "Luigi Vanvitelli”, 81100 Caserta, Italy; petronia.carillo@unicampania.it \\ * Correspondence: youssef.rouphael@unina.it; Tel.: +39-(081)-2539134
}

Academic Editor: Isabel C.F.R. Ferreira

Received: 21 December 2018; Accepted: 29 December 2018; Published: 6 January 2019

check for updates

\begin{abstract}
Consumer demand for fresh and functional horticultural products is on the rise. Perilla frutescens, L. Britt (Lamiaceae) is a potential specialty/niche crop for consumption and therapeutic uses with high contents of phenolic and volatile compounds. Plant growth, mineral composition, polyphenol profile and aroma volatile components of two perilla genotypes in response to salinity (non-salt control, 10, 20 or $30 \mathrm{mM} \mathrm{NaCl}$ ) applied as chemical eustressor were assessed. Salinity suppressed growth and yield of both genotypes, although the red-pigmented genotype was less sensitive than the green-pigmented one. Mild $(10 \mathrm{mM} \mathrm{NaCl})$ and moderate $(20$ and $30 \mathrm{mM}$ $\mathrm{NaCl}$ ) salinity suppressed foliar potassium, magnesium, nitrate and chlorophyll a concentrations of both genotypes and increased the levels of rosmarinic acid, total polyphenols and target aroma volatile components. Green perilla showed higher yield and biomass production and higher content of protein, dry matter, calcium, magnesium, perilla ketone and cis-jasmone, whereas red perilla exhibited higher content of potassium, chlorophyll a, rosmarinic acid, total polyphenols, perilla aldehyde and benzaldehyde. Our findings support that chemical eustressors such as mild to moderate salinity offer valuable means to manipulate phytochemical and aroma profiles.
\end{abstract}

Keywords: macro-minerals; functional food; perillaldehyde; phenolic compounds; sodium chloride; SPME-GC/MS; volatile profile

\section{Introduction}

Consumer interest in functional diets supporting human health and longevity has rapidly expanded worldwide and consequently demand for healthier and organoleptically appealing fresh horticultural products has increased. These changes in consumer behavior have fueled the critical reassessment of the quality of fresh horticultural products as a concept, concisely defined in a recent review as 'a dynamic composite of physicochemical properties and evolving consumer perception, which embraces organoleptic, nutritional and bioactive components' [1]. The bioactive components of fresh horticultural products have been the key ingredients used to generate a wide range of novel functional foods [2]. In addition, horticultural products can provide ingredients of natural-origin able to fulfill the food-preserving functions exerted by synthetic antioxidants [3]. Functional foods and natural food ingredients have thus become major lines of the global food industry, driven by increasing 
consumer demand, price premiums, and improving market opportunities [4]. Consequentially, growers, extension specialists and scientists have become increasingly interested in new and/or niche horticultural species rich in bioactive metabolites suitable for the production of supplements with nutraceutical, therapeutic or preservative activity [5].

Perilla frutescens, L. Britt Lamiaceae (formely Labiateae), an edible and medicinal plant used traditionally in China, Japan and other Asian countries, has recently gained wider acclaim and high value [6]. Nowadays, its cultivation in the United States, North and South Africa and Europe is widespread, with notable economic returns [7]. The seeds, leaves, and stems of this species contain vitamins, minerals, essential oils and phenolic phytochemicals valued by the food industry as flavoring and antioxidant agents for foods and drinks, and in the pharmaceutical industry as anti-allergic, anti-inflammatory and anti-oncogenic agents $[5,8,9]$. Perilla is present in nature in two, genetically discrete, main chemo-varietal phenotypes: the anthocyanin-rich red-pigmented cultivar known as "Zi-So", widely grown in China, and the non-pigmented green cultivar mainly present in Japan and known as "Shisoyo" or "Shiso" $[10,11]$. Red perilla is mainly used for its antioxidant activity and as a food colorant [12], while the green phenotype is mainly used for food, skin cream, and medicines for allergic dermatitis [13]. Chinese and Japanese restaurants widely use Zi-So or Shiso leaves to accompany various fish dishes, in particular with Sa-Shi-Mi (fresh fish slices), not only as a fragrant condiment but also because of its bioactive properties that fence food against microbial contamination [14]. The main active phytochemicals of perilla are perillaldehyde, an essential oil which imparts the unique and characteristic flavor to the plant leaves, and rosmarinic acid, a phenolic acid used for culinary and clinical applications $[15,16]$.

Perilla usually grows in wild areas or is cultured outdoors under growing conditions and practices that do not guarantee standardized quality and bioactive content, which may additionally vary in relation to the genetic material used (e.g., green vs. red perilla) $[1,16]$. Given the important properties of this plant and its high economic value, extensive research has been conducted concerning the effects of crop nutrition and environmental conditions on its metabolite profile [17]. However, few scientific papers have described the positive effects of environmental factors on crop performance and especially on the quality traits of this valuable novel crop. In fact, in studies of the modulation of phenolic phytochemicals in both red and green perilla grown under field conditions and harvested in different seasons and years [5,15], or grown in controlled conditions under 100-300 $\mu \mathrm{E}$ PPFD combined with 1-3 dS $\cdot \mathrm{m}^{-1}$ of nutrient solution electrical conductivity [16], only the unfavorable effects of the studied environmental factors were considered. On the contrary, recent studies on the effect of combined or milder environmental stresses on plants have shown tailored responses ascribable to the stress-related plasticity of plants which can strategically command metabolic reshuffling and accumulation of bioactive compounds in order to cope with stress-induced sub-optimal conditions [1,18-20]. In particular, positive stress administered at low intensity, also known as eustress, can trigger the biosynthesis and accumulation of bioactive secondary compounds (carotenoids, phenolic compounds, organosulfuric compounds, polyamines etc.) which enhance the functional properties and the nutritional value of the final product [21,22]. Stress elicits dose-dependent responses, or as stated by Paracelsus 'dose makes the poison'. Among the known types of eustress, salinity is one able to improve the quality of horticultural products provided an optimal, mild dose is used, in compliance to the famous sectiodivina. Recently, Petropoulos et al. [23] found that moderate salinity levels (up to $6.0 \mathrm{dS} \cdot \mathrm{m}^{-1}$ ) increased the ascorbic acid and $\alpha$-tocopherol contents and the antioxidant activity of the important leafy vegetable Cichorium spinosum. Beneficial effects of mild salt-stress $(<30 \mathrm{mM} \mathrm{NaCl})$ were also demonstrated in artichoke and cardoon leaves, which showed an increase of total phenolics, chlorogenic acid, cynarin and luteolin contents and antioxidant activity [24]. However, since response to salt-stress is a cultivar-dependent feature, the choice of proper genotype is crucial for achieving high phytochemical concentrations using salinity eustress [21,22].

To our knowledge, nothing is known regarding the ability of salinity as a eustress factor or as a chemical eustressor to modulate leaf secondary metabolites and aroma volatiles, nor regarding the 
salinity-genotype interaction in perilla species as a means for improving leaf quality. With respect to the above considerations, our aim was to assess the effect of mild to moderate salinity levels applied in the nutrient solution on productivity, colorimetry, mineral composition, protein content, polyphenol profile and aroma volatile components of red and green-pigmented perilla genotypes grown in soilless culture.

\section{Results and Discussion}

\subsection{Fresh Yield, Growth Response and Colorimetric Attributes}

Plant final height and leaf area were influenced by salinity and genotype with no significant salinity $\times$ genotype interaction, whereas the leaf number, leaf fresh yield, as well as dry shoot biomass were affected by salinity $\times$ genotype interaction (Table 1 ). The significant depression of plant growth parameters (leaf number and area, leaf fresh yield and dry biomass) with increasing salinity level in the nutrient solution has been demonstrated in previous greenhouse studies on cardoon/artichoke and spiny chicory $[23,24]$. Intra-specific cultivars/genotypes may develop different salt-tolerance mechanisms depending on the severity of stress in terms of concentration and time of exposure [21,22]. This was the case in the current study since the fresh yield and dry biomass of both genotypes decreased with increasing salinization, although the red-pigmented genotype was less affected than green-pigmented one at 20 and $30 \mathrm{mM} \mathrm{NaCl}$. Specifically, the percentage of fresh yield reduction in comparison to non-salinized control plants was $7.8 \%, 16.5 \%$ and $48.6 \%$ in red perilla and $22.0 \%$, $44.4 \%$ and $78.0 \%$ in green perilla at 10,20 and $30 \mathrm{mM} \mathrm{NaCl}$ concentration in the nutrient solution, respectively (Table 1). This differential genotype response was also confirmed for dry shoot biomass and leaf number. The higher sensitivity of green perilla to salinity is attributed to the higher sodium concentrations in leaf tissue compared to red perilla (Table 2). Averaged over salt treatment levels, red perilla was able to accumulate $48.5 \%$ less sodium and to maintain potassium-to-sodium ratio (salt tolerance indicator) two-fold higher than the green cultivar (Table 2). The improved crop performance of red perilla in terms of fresh yield and dry biomass at the three levels of salinity stress applied could be associated to decreased stomatal resistance, which enhances the net $\mathrm{CO}_{2}$ assimilation rate (data not shown), and consequently plant vegetative growth and productivity. Moreover, it is worth noting that the tested genotypes demonstrated marked differences in their fresh yield and dry biomass potential. Under non-saline conditions, the fresh and dry yield of green perilla was respectively $43 \%$ and $68 \%$ higher than that of red perilla (Table 1). This is in agreement with previous research which demonstrated that green perilla cultivars generally grow faster than red ones under both controlled and open-field conditions [16,25].

Among the physical properties of leafy vegetables that strongly influence consumer preference, acceptability and choice making is visual appearance, in particular leaf color [26,27]. The coloring pigments (i.e., carotenoids, phenols, anthocyanins and betalains) may also be considered as an indicator for estimating the antioxidant properties of edible and medicinal plants, where red and dark green colored leafy vegetables are richer in nutrient content than lighter colored vegetables [28]. This was the case in the present study where genotype was expectedly the determining factor affecting Perilla leaf color, given that cultivars of distinct colorimetry were examined. The highest redness values recorded in red perilla were expectable since this chemotype is characterized by high presence of specific pigments (phenols and anthocyanins) involved in leaf coloration. Less significant was the effect of salinity on leaf brightness $\left(\mathrm{L}^{*}\right)$, which overall increased in response to increasing $\mathrm{NaCl}$ concentration in the nutrient solution (Table 1). The predominance of the genotypic effect completely masked the effects of salinity on color components $\mathrm{a}^{*}$ and $\mathrm{b}^{*}$. However, a closer look at color component $\mathrm{a}^{*}$ shows that in the green cultivar it dropped in response to the $30 \mathrm{mM} \mathrm{NaCl}$ treatment, denoting loss of greenness and a transition towards the achromatic center of the CIELAB chromatic sphere [29]. A one-way analysis of variance (data not presented) within cultivars confirmed the significance of this effect on the more salt-sensitive green cultivar. 
Table 1. Analysis of variance and mean comparisons for plant height, number of leaves per plant, total leaf area, leaf fresh weight, shoot dry biomass, and leaf colour: $\mathrm{L}^{*}$ (brightness), $\mathrm{a}^{*}\left(+\mathrm{a}^{*}=\right.$ red; $-\mathrm{a}^{*}=$ green $)$ and $\mathrm{b}^{*}\left(+\mathrm{b}^{*}=\right.$ yellow; $\left.-\mathrm{b}=\mathrm{blue}\right)$ in green and red perilla grown under increasing NaCl concentration in the nutrient solution.

\begin{tabular}{|c|c|c|c|c|c|c|c|c|}
\hline \multirow{2}{*}{ Source of Variance } & \multirow{2}{*}{$\begin{array}{c}\text { Plant Height } \\
\text { (cm) }\end{array}$} & \multirow{2}{*}{ 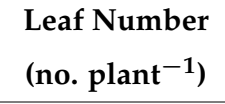 } & \multirow{2}{*}{$\begin{array}{c}\text { Leaf Area } \\
\left(\mathrm{cm}^{2} \cdot \text { plant }^{-1}\right)\end{array}$} & \multirow{2}{*}{$\begin{array}{c}\text { Leaf Fresh Yield } \\
\left(\mathrm{g} \cdot \text { plant }^{-1}\right)\end{array}$} & \multirow{2}{*}{$\begin{array}{c}\text { Shoot Dry Biomass } \\
\left(\mathrm{g} \cdot \text { plant }^{-1}\right)\end{array}$} & \multicolumn{3}{|c|}{ Leaf Colour } \\
\hline & & & & & & $\mathbf{L}^{*}$ & $a^{*}$ & $\mathbf{b}^{*}$ \\
\hline Genotype (G) & * & NS & * & NS & $* *$ & $* * *$ & $* * *$ & $* * *$ \\
\hline Salinity (S) & $* *$ & $* * *$ & $* * *$ & $* * *$ & $* * *$ & * & NS & NS \\
\hline $\mathrm{C} \times \mathrm{S}$ & NS & $* *$ & NS & $*$ & $* *$ & NS & NS & NS \\
\hline \multicolumn{9}{|l|}{ Genotype } \\
\hline Green & $44.2 \pm 2.2 \mathrm{a}$ & $115.0 \pm 13.9 \mathrm{a}$ & $1984.7 \pm 288.1 b$ & $50.3 \pm 10.1 \mathrm{a}$ & $15.8 \pm 1.7 \mathrm{a}$ & $36.0 \pm 0.7 \mathrm{a}$ & $-6.7 \pm 0.5 b$ & $15.2 \pm 0.6 \mathrm{a}$ \\
\hline $\begin{array}{l}\text { Red } \\
\text { Salinity (mM NaCl) }\end{array}$ & $39.2 \pm 1.3 \mathrm{~b}$ & $121.1 \pm 6.5 \mathrm{a}$ & $2422.3 \pm 182.2 \mathrm{a}$ & $45.2 \pm 4.5 \mathrm{a}$ & $11.8 \pm 0.7 \mathrm{~b}$ & $25.9 \pm 0.7 \mathrm{~b}$ & $4.5 \pm 0.3 \mathrm{a}$ & $0.9 \pm 0.5 b$ \\
\hline 1 & $47.4 \pm 2.6 \mathrm{a}$ & $164.2 \pm 8.7 \mathrm{a}$ & $3216.2 \pm 174.3 \mathrm{a}$ & $67.0 \pm 9.5 \mathrm{a}$ & $18.9 \pm 1.9 \mathrm{a}$ & $28.9 \pm 2.7 \mathrm{c}$ & $-1.0 \pm 2.8 \mathrm{a}$ & $8.3 \pm 3.6 \mathrm{a}$ \\
\hline 10 & $43.8 \pm 2.4 \mathrm{ab}$ & $132.7 \pm 6.7 \mathrm{~b}$ & $2564.5 \pm 132.2 \mathrm{~b}$ & $56.3 \pm 6.6 \mathrm{ab}$ & $15.2 \pm 1.0 \mathrm{~b}$ & $29.9 \pm 2.4 b c$ & $-1.9 \pm 2.6 \mathrm{a}$ & $8.1 \pm 3.1 \mathrm{a}$ \\
\hline 20 & $40.9 \pm 1.8 b$ & $105.9 \pm 10.1 \mathrm{c}$ & $1983.0 \pm 260.0 \mathrm{c}$ & $45.0 \pm 8.2 \mathrm{~b}$ & $13.0 \pm 1.1 \mathrm{~b}$ & $32.9 \pm 2.3 \mathrm{a}$ & $-1.6 \pm 2.6 \mathrm{a}$ & $9.3 \pm 3.3 \mathrm{a}$ \\
\hline 30 & $34.7 \pm 1.7 c$ & $69.4 \pm 8.9 \mathrm{~d}$ & $1050.1 \pm 221.0 \mathrm{~d}$ & $22.8 \pm 5.6 c$ & $7.0 \pm 1.2 \mathrm{c}$ & $32.1 \pm 2.0 \mathrm{ab}$ & $0.1 \pm 2.3 \mathrm{a}$ & $6.5 \pm 3.1 \mathrm{a}$ \\
\hline \multicolumn{9}{|l|}{$\mathrm{G} \times \mathrm{S}$} \\
\hline Green-1 mM NaCl & $52.2 \pm 3.4 \mathrm{a}$ & $184.2 \pm 8.7 \mathrm{a}$ & $3269.1 \pm 332.3 \mathrm{a}$ & $78.8 \pm 8.4 \mathrm{a}$ & $23.7 \pm 1.2 \mathrm{a}$ & $34.9 \pm 0.7 \mathrm{a}$ & $-7.1 \pm 0.5 \mathrm{a}$ & $16.3 \pm 1.2 \mathrm{a}$ \\
\hline Green- $10 \mathrm{mM} \mathrm{NaCl}$ & $47.4 \pm 4.0 \mathrm{a}$ & $132.1 \pm 14 . \mathrm{b}$ & $2421.1 \pm 244.0 \mathrm{a}$ & $61.5 \pm 10.1 \mathrm{ab}$ & $17.5 \pm 0.8 \mathrm{~b}$ & $35.2 \pm 0.1 \mathrm{a}$ & $-7.6 \pm 0.6 \mathrm{a}$ & $15.0 \pm 0.3 \mathrm{a}$ \\
\hline Green-20 mM NaCl & $41.0 \pm 2.4 \mathrm{a}$ & $93.2 \pm 13.5 c$ & $1648.1 \pm 396.2 \mathrm{a}$ & $43.8 \pm 15.0 \mathrm{bc}$ & $13.2 \pm 2.0 \mathrm{bc}$ & $37.4 \pm 2.3 \mathrm{a}$ & $-7.3 \pm 0.5 \mathrm{a}$ & $16.4 \pm 1.9 \mathrm{a}$ \\
\hline Green-30 mM NaCl & $36.4 \pm 3.5 \mathrm{a}$ & $50.5 \pm 1.4 \mathrm{~d}$ & $607.0 \pm 182.3 \mathrm{a}$ & $17.3 \pm 11.7 \mathrm{~d}$ & $6.5 \pm 2.3 \mathrm{~d}$ & $36.3 \pm 1.8 \mathrm{a}$ & $-5.1 \pm 1.4 \mathrm{a}$ & $13.3 \pm 1.0 \mathrm{a}$ \\
\hline Red- $1 \mathrm{mM} \mathrm{NaCl}$ & $42.6 \pm 2.3 \mathrm{a}$ & $144.2 \pm 2.7 \mathrm{~b}$ & $3163.2 \pm 169.3 \mathrm{a}$ & $55.1 \pm 2.2 \mathrm{~b}$ & $14.1 \pm 0.5 \mathrm{bc}$ & $22.9 \pm 1.1 \mathrm{a}$ & $5.1 \pm 0.8 \mathrm{a}$ & $0.2 \pm 0.1 \mathrm{a}$ \\
\hline Red-10 mM NaCl & $40.4 \pm 1.2 \mathrm{a}$ & $133.3 \pm 2.8 \mathrm{~b}$ & $2708.0 \pm 90.5 \mathrm{a}$ & $50.8 \pm 2.5 \mathrm{~b}$ & $12.8 \pm 0.1 \mathrm{c}$ & $24.4 \pm 0.4 \mathrm{a}$ & $3.8 \pm 0.6 \mathrm{a}$ & $1.3 \pm 0.8 \mathrm{a}$ \\
\hline Red-20 mM NaCl & $40.7 \pm 2.9 \mathrm{a}$ & $118.6 \pm 13.6 \mathrm{bc}$ & $2317.8 \pm 288.0 \mathrm{a}$ & $46.0 \pm 9.2 \mathrm{bc}$ & $13.0 \pm 1.3 \mathrm{c}$ & $28.4 \pm 0.5 \mathrm{a}$ & $4.1 \pm 0.1 \mathrm{a}$ & $2.3 \pm 0.8 \mathrm{a}$ \\
\hline Red-30 mM NaCl & $33.7 \pm 1.8 \mathrm{a}$ & $88.2 \pm 7.9 c$ & $1500.2 \pm 208.6 \mathrm{a}$ & $28.3 \pm 5.9 \mathrm{~cd}$ & $7.4 \pm 1.2 \mathrm{~d}$ & $27.9 \pm 0.4 \mathrm{a}$ & $4.9 \pm 0.5 \mathrm{a}$ & $-0.4 \pm 1.4 \mathrm{a}$ \\
\hline
\end{tabular}

NS, ${ }^{*}, * *, * * *$ Nonsignificant or significant at $p \leq 0.05,0.01$, and 0.001 , respectively. Different letters within each column indicate significant differences according to Duncan's multiple-range test $(p=0.05)$. All data are expressed as mean \pm standard error, $n=3$. 
Table 2. Analysis of variance and mean comparisons for mineral composition of leaves in green and red perilla grown under increasing $\mathrm{NaCl}$ concentration in the nutrient solution.

\begin{tabular}{|c|c|c|c|c|c|c|c|c|}
\hline \multirow{2}{*}{ Source of Variance } & \multirow{2}{*}{$\begin{array}{l}\text { Leaf Dry } \\
\text { Matter (\%) }\end{array}$} & \multirow{2}{*}{$\begin{array}{c}\text { Protein } \\
\left(\mathrm{g} \cdot \mathrm{kg}^{-1} \mathrm{dw}\right)\end{array}$} & \multicolumn{6}{|c|}{ Mineral Elements $\left(\mathrm{g} \cdot \mathrm{kg}^{-1} \mathrm{dw}\right)$} \\
\hline & & & $\mathrm{PO}_{4}{ }^{3-}$ & $\mathrm{K}^{+}$ & $\mathrm{Ca}^{2+}$ & $\mathrm{Mg}^{2+}$ & $\mathrm{SO}_{4}^{2-}$ & $\mathrm{Na}^{+}$ \\
\hline Genotype (G) & $* * *$ & $* * *$ & NS & $* *$ & $* * *$ & $* * *$ & NS & $* * *$ \\
\hline Salinity $(S)$ & $* * *$ & $* * *$ & $* *$ & $*$ & $*$ & $* *$ & NS & $* * *$ \\
\hline $\mathrm{C} \times \mathrm{S}$ & $* * *$ & $*$ & NS & NS & NS & NS & NS & $* *$ \\
\hline \multicolumn{9}{|l|}{ Genotype } \\
\hline Green & $20.8 \pm 0.4 \mathrm{a}$ & $256.9 \pm 5.1 \mathrm{a}$ & $14.0 \pm 0.8 \mathrm{a}$ & $27.7 \pm 0.6 b$ & $12.2 \pm 0.3 \mathrm{a}$ & $2.4 \pm 0.13 \mathrm{a}$ & $0.3 \pm 0.0 \mathrm{a}$ & $6.6 \pm 1.4 \mathrm{a}$ \\
\hline Red & $19.1 \pm 0.6 \mathrm{~b}$ & $234.7 \pm 7.9 \mathrm{~b}$ & $12.6 \pm 0.8 \mathrm{a}$ & $29.0 \pm 0.7 \mathrm{a}$ & $7.1 \pm 0.3 \mathrm{~b}$ & $1.7 \pm 0.06 \mathrm{~b}$ & $0.3 \pm 0.0 \mathrm{a}$ & $3.4 \pm 0.8 \mathrm{~b}$ \\
\hline \multicolumn{9}{|l|}{ Salinity (mM NaCl) } \\
\hline 1 & $17.2 \pm 0.4 \mathrm{~d}$ & $277.8 \pm 3.3 \mathrm{a}$ & $16.2 \pm 1.3 \mathrm{a}$ & $30.3 \pm 0.8 \mathrm{a}$ & $8.4 \pm 1.3 \mathrm{~b}$ & $2.3 \pm 0.23 \mathrm{a}$ & $0.3 \pm 0.0 \mathrm{a}$ & $0.2 \pm 0.1 \mathrm{~d}$ \\
\hline 10 & $19.2 \pm 0.6 c$ & $254.6 \pm 5.1 \mathrm{~b}$ & $13.9 \pm 0.6 \mathrm{ab}$ & $29.3 \pm 1.0 \mathrm{a}$ & $10.0 \pm 1.3 \mathrm{a}$ & $2.3 \pm 0.22 \mathrm{a}$ & $0.2 \pm 0.0 \mathrm{a}$ & $2.9 \pm 0.7 \mathrm{c}$ \\
\hline 20 & $21.1 \pm 0.2 \mathrm{~b}$ & $229.7 \pm 7.0 \mathrm{c}$ & $10.6 \pm 0.4 b c$ & $27.1 \pm 0.5 \mathrm{~b}$ & $10.0 \pm 0.8 \mathrm{a}$ & $1.9 \pm 0.14 b$ & $0.2 \pm 0.0 \mathrm{a}$ & $7.4 \pm 1.3 \mathrm{~b}$ \\
\hline 30 & $22.0 \pm 0.3 a$ & $220.9 \pm 7.5 \mathrm{~d}$ & $12.2 \pm 0.6 \mathrm{c}$ & $26.5 \pm 0.7 \mathrm{~b}$ & $10.1 \pm 1.3 \mathrm{a}$ & $1.7 \pm 0.12 b$ & $0.3 \pm 0.0 \mathrm{a}$ & $9.4 \pm 1.2 \mathrm{a}$ \\
\hline \multicolumn{9}{|l|}{$\mathrm{G} \times \mathrm{S}$} \\
\hline Green-1 mM NaCl & $18.3 \pm 0.2 c$ & $282.0 \pm 2.1 \mathrm{a}$ & $16.8 \pm 2.1 \mathrm{a}$ & $28.9 \pm 0.6 \mathrm{a}$ & $11.4 \pm 0.1 \mathrm{a}$ & $2.8 \pm 0.29 \mathrm{a}$ & $0.3 \pm 0.0 \mathrm{a}$ & $0.1 \pm 0.0 \mathrm{~d}$ \\
\hline Green-10 mM NaCl & $20.8 \pm 0.1 b$ & $263.9 \pm 6.0 \mathrm{~b}$ & $14.7 \pm 0.8 \mathrm{a}$ & $28.7 \pm 1.9 \mathrm{a}$ & $12.9 \pm 0.6 \mathrm{a}$ & $2.7 \pm 0.22 \mathrm{a}$ & $0.3 \pm 0.0 \mathrm{a}$ & $4.3 \pm 0.8 \mathrm{c}$ \\
\hline Green-20 mM NaCl & $21.5 \pm 0.4 \mathrm{ab}$ & $244.4 \pm 1.5 c$ & $10.9 \pm 0.5 a$ & $26.5 \pm 1.0 \mathrm{a}$ & $11.8 \pm 0.2 \mathrm{a}$ & $2.2 \pm 0.19 a$ & $0.2 \pm 0.1 \mathrm{a}$ & $10.1 \pm 0.7 \mathrm{a}$ \\
\hline Green-30 mM NaCl & $22.4 \pm 0.7 \mathrm{a}$ & $237.1 \pm 1.5 c$ & $13.4 \pm 0.8 \mathrm{a}$ & $26.1 \pm 0.3 \mathrm{a}$ & $12.8 \pm 0.9 a$ & $2.0 \pm 0.02 \mathrm{a}$ & $0.3 \pm 0.0 \mathrm{a}$ & $11.8 \pm 1.0 \mathrm{a}$ \\
\hline Red-1 mM NaCl & $16.1 \pm 0.1 \mathrm{~d}$ & $274.0 \pm 2.1 \mathrm{a}$ & $15.5 \pm 2.0 \mathrm{a}$ & $31.7 \pm 0.9 \mathrm{a}$ & $5.4 \pm 0.3 \mathrm{a}$ & $1.9 \pm 0.05 \mathrm{a}$ & $0.2 \pm 0.0 \mathrm{a}$ & $0.3 \pm 0.2 \mathrm{~d}$ \\
\hline Red-10 mM NaCl & $17.6 \pm 0.3 c$ & $245.3 \pm 5.2 \mathrm{ab}$ & $13.3 \pm 0.9 \mathrm{a}$ & $29.8 \pm 1.3 \mathrm{a}$ & $7.0 \pm 0.2 \mathrm{a}$ & $1.9 \pm 0.15 \mathrm{a}$ & $0.2 \pm 0.1 \mathrm{a}$ & $1.6 \pm 0.3 \mathrm{~d}$ \\
\hline Red-20 mM NaCl & $20.7 \pm 0.1 b$ & $214.9 \pm 4.0 \mathrm{c}$ & $10.4 \pm 0.7 \mathrm{a}$ & $27.6 \pm 0.4 \mathrm{a}$ & $8.3 \pm 0.3 \mathrm{a}$ & $1.7 \pm 0.05 \mathrm{a}$ & $0.3 \pm 0.1 \mathrm{a}$ & $4.6 \pm 1.0 \mathrm{c}$ \\
\hline Red-30 mM NaCl & $21.7 \pm 0.1 \mathrm{ab}$ & $204.7 \pm 2.2 \mathrm{~d}$ & $11.5 \pm 0.5 \mathrm{a}$ & $26.8 \pm 1.4 \mathrm{a}$ & $7.5 \pm 0.5 \mathrm{a}$ & $1.5 \pm 0.07 \mathrm{a}$ & $0.3 \pm 0.1 \mathrm{a}$ & $7.1 \pm 0.8 \mathrm{~b}$ \\
\hline
\end{tabular}

$N S_{, * * * * *}^{*}$ Nonsignificant or significant at $p \leq 0.05,0.01$ and 0.001 , respectively. Different letters within each column indicate significant differences according to Duncan's multiple-range test $(p=0.05)$. All data are expressed as mean \pm standard error, $n=3$. 


\subsection{Dry Matter, Protein Content and Mineral Profile}

The leaf dry matter (DM) content recorded in the green and red perilla plants ranged from $18.3 \%$ to $22.4 \%$ and from $16.1 \%$ to $21.7 \%$, respectively (Table 2). Salt treatment increased the leaf DM percentage with the highest values observed in green perilla at 20 and $30 \mathrm{mM}$ as well as in red perilla plants at $30 \mathrm{mM} \mathrm{NaCl}$ (Table 2). Analysis of variance also highlighted that the genotype $\times$ salinity interaction was significant for proteins with the highest values observed in green and red perilla under non-saline conditions (Table 2). Our findings on the proteins content (237-282 and 204-274 $\mathrm{g} \cdot \mathrm{kg}^{-1} \mathrm{dw}$ in green and red perilla, respectively) were proximate to the 130 and $206 \mathrm{~g} \cdot \mathrm{kg}^{-1} \mathrm{dw}$ reported by Peiretti [30] on Perilla frutescens harvested at three morphological stages (42, 49 and 52 days after sowing).

It is well known that the presence of major minerals ( $\mathrm{P}, \mathrm{S}, \mathrm{K}, \mathrm{Ca}$ and $\mathrm{Mg}$ ) in the human diet is crucial since these macronutrients have multiple properties and functionality for human metabolism and homeostasis [31]. In fact, Levander [32] stated that fruits and vegetables normally contribute $11 \%, 35 \%, 7 \%$ and $24 \%$ of the total human dietary intake of phosphorus, potassium, calcium and magnesium, respectively. Among the macro cations and anions analyzed, $\mathrm{K}+$ was the main mineral constituent followed by $\mathrm{PO}_{4}{ }^{3-}, \mathrm{Ca}^{2+}, \mathrm{Mg}^{2+}$ and finally $\mathrm{SO}_{4}{ }^{2-}$ (Table 2). To our knowledge, this is the first scientific work reporting the leaf mineral profile of green and red perilla plants, which could constitute an important information for the food composition databases.

Concerning the influence of genetic material on mineral composition, significant variation was recorded for $\mathrm{K}^{+}, \mathrm{Ca}^{2+}, \mathrm{Mg}^{2+}$ and $\mathrm{Na}^{+}$, whereas neither genotype nor salinity treatment had a significant effect on $\mathrm{SO}_{4}{ }^{2-}$ concentration in leaves (avg. $0.27 \mathrm{~g} \cdot \mathrm{kg}^{-1} \mathrm{dw}$; Table 2). The highest values of calcium, magnesium and sodium were recorded in green perilla, whereas an opposite trend was observed for potassium with the highest concentration observed in red perilla (Table 2). Nutritional interest in vegetables such as perilla containing high concentrations of minerals $\left(\mathrm{K}^{+}\right.$in red perilla, $\mathrm{Ca}^{2+}$ and $\mathrm{Mg}^{2+}$ in green perilla) has been associated with the health-promoting functions of these macro-minerals, such as lowering of blood pressure and waste elimination (for $\mathrm{K}$ ), enhancement of skeletal health as well as reduced incidence of osteoporosis (for $\mathrm{Ca}$ and $\mathrm{Mg}$ ) [31]. The $\mathrm{PO}_{4}{ }^{3-}, \mathrm{K}^{+}, \mathrm{Ca}^{2+}$ and $\mathrm{Mg}^{2+}$ concentrations in both green and red perilla leaves were negatively influenced by salt stress treatment but only at 20 and $30 \mathrm{mM} \mathrm{NaCl}$ (Table 2). The nutritional disorder incurred by perilla plants at 20 and $30 \mathrm{mM} \mathrm{NaCl}$ has been associated to several mechanisms, including: (i) osmotic effects of $\mathrm{Na}^{+}$ and $\mathrm{Cl}^{-}$; (ii) reduction in cell membrane integrity (i.e., permeability); and (iii) alteration in the uptake and translocation of monovalent $\left(\mathrm{K}^{+}\right)$and bivalent cations $\left(\mathrm{Ca}^{2+}\right.$ and $\left.\mathrm{Mg}^{2+}\right)$ due to the competitive interactions with $\mathrm{Na}^{+}$[33]. Therefore, green and to a much lesser degree red perilla plants become more sensitive to $\mathrm{Na}^{+}$and/or $\mathrm{Cl}^{-}$injuries (especially with 20 and $30 \mathrm{mM} \mathrm{NaCl}$ ), resulting in biomass reduction and fresh yield loss

\subsection{Nitrate and Chlorophyll a Contents, Phenolic Composition and Total Phenolic Content}

From a botanical point of view, vegetable crops belonging to the family of Lamiaceae (i.e., basil, thyme) are classified as high nitrate accumulating species $\left(2500-5000 \mathrm{mg} \cdot \mathrm{kg}^{-1} \mathrm{fw}\right.$ [34]. This was the case in the current study, since the nitrate contents of green and red perilla under non-saline control were 2825 and $2780 \mathrm{mg} \cdot \mathrm{kg}^{-1} \mathrm{fw}$, respectively, with no significant differences between the two perilla genotypes (Table 3). Interestingly, the addition of $\mathrm{NaCl}$ in the nutrient solution could be considered a useful tool for mitigating the high accumulation of anti-nutrients (nitrate) in both perilla cultivars, due to the well-known antagonism effect between these two monovalent anions $\left(\mathrm{NO}_{3}{ }^{-}\right.$and $\left.\mathrm{Cl}^{-}\right)$. In our experiment, concentrations of both sodium and chloride in the root zone decreased the nitrate uptake, translocation and accumulation in perilla leaves by $34 \%$. A putative mechanism behind the decrease in nitrate concentration could be the reduced plant growth rate and development, leading to a down regulation of net nitrate uptake through a lower request for nitrogen $[35,36]$. 
Table 3. Analysis of variance and mean comparisons for protein, nitrate and chlorophyll a contents, target phenolic acids and total polyphenols in green and red perilla grown under increasing $\mathrm{NaCl}$ concentration in the nutrient solution.

\begin{tabular}{|c|c|c|c|c|c|c|}
\hline Source of Variance & $\begin{array}{c}\text { Nitrate } \\
\left(\mathrm{mg} \cdot \mathrm{kg}^{-1} \mathrm{fw}\right)\end{array}$ & $\begin{array}{l}\text { Chlorophyll a } \\
\left(\mathrm{mg} \cdot \mathrm{g}^{-1} \mathrm{dw}\right)\end{array}$ & $\begin{array}{l}\text { Rosmarinic Acid } \\
\left(\mathrm{mg} \cdot \mathrm{g}^{-1} \mathrm{dw}\right)\end{array}$ & $\begin{array}{l}\text { Caffeic Acid } \\
\left(\mathrm{mg} \cdot \mathrm{g}^{-1} \mathrm{dw}\right)\end{array}$ & $\begin{array}{l}\text { Sinapic Acid } \\
\left(\mathrm{mg} \cdot \mathrm{g}^{-1} \mathrm{dw}\right)\end{array}$ & $\begin{array}{l}\text { Total Polyphenols } \\
\left(\mathrm{mg} \cdot \mathrm{g}^{-1} \mathrm{dw}\right)\end{array}$ \\
\hline Genotype (G) & NS & $* *$ & NS & NS & $* * *$ & $* * *$ \\
\hline Salinity (S) & $* *$ & $* *$ & $*$ & NS & NS & $* * *$ \\
\hline$C \times S$ & * & NS & NS & NS & NS & $* *$ \\
\hline \multicolumn{7}{|l|}{ Genotype } \\
\hline Green & $1937.1 \pm 209.1 \mathrm{a}$ & $64.1 \pm 5.1 b$ & $15.7 \pm 1.4 \mathrm{a}$ & $0.3 \pm 0.0 \mathrm{a}$ & $0.1 \pm 0.0 \mathrm{~b}$ & $63.6 \pm 3.0 \mathrm{~b}$ \\
\hline Red & $1727.6 \pm 209.0 \mathrm{a}$ & $81.3 \pm 8.2 \mathrm{a}$ & $15.6 \pm 1.8 \mathrm{a}$ & $0.3 \pm 0.0 \mathrm{a}$ & $1.2 \pm 0.0 \mathrm{a}$ & $93.7 \pm 2.0 \mathrm{a}$ \\
\hline \multicolumn{7}{|l|}{ Salinity (mM NaCl) } \\
\hline 1 & $2803.2 \pm 205.2 \mathrm{a}$ & $93.3 \pm 12.6 \mathrm{a}$ & $9.7 \pm 2.0 \mathrm{~b}$ & $0.3 \pm 0.0 \mathrm{a}$ & $0.7 \pm 0.3 \mathrm{a}$ & $71.8 \pm 6.6 c$ \\
\hline 10 & $1859.7 \pm 186.3 b$ & $73.0 \pm 7.1 b$ & $18.4 \pm 2.7 \mathrm{a}$ & $0.3 \pm 0.0 \mathrm{a}$ & $0.7 \pm 0.3 \mathrm{a}$ & $89.7 \pm 6.0 \mathrm{a}$ \\
\hline 20 & $1299.6 \pm 123.4 c$ & $65.1 \pm 6.6 b$ & $16.5 \pm 0.8 \mathrm{a}$ & $0.3 \pm 0.0 \mathrm{a}$ & $0.6 \pm 0.2 \mathrm{a}$ & $82.9 \pm 6.2 b$ \\
\hline 30 & $1366.8 \pm 106.3 c$ & $58.8 \pm 6.5 b$ & $18.1 \pm 0.5 \mathrm{a}$ & $0.3 \pm 0.0 \mathrm{a}$ & $0.6 \pm 0.3 \mathrm{a}$ & $70.3 \pm 8.3 c$ \\
\hline \multicolumn{7}{|l|}{$G \times S$} \\
\hline Green-1 mM NaCl & $2780.9 \pm 397.3 \mathrm{a}$ & $74.6 \pm 0.6 \mathrm{a}$ & $12.1 \pm 3.4 \mathrm{a}$ & $0.4 \pm 0.0 \mathrm{a}$ & $0.1 \pm 0.0 \mathrm{a}$ & $57.4 \pm 2.3 \mathrm{f}$ \\
\hline Green-10 mM NaCl & $2259.3 \pm 99.3 \mathrm{a}$ & $71.4 \pm 9.9 \mathrm{a}$ & $14.7 \pm 3.4 \mathrm{a}$ & $0.3 \pm 0.1 \mathrm{a}$ & $0.1 \pm 0.0 \mathrm{a}$ & $76.3 \pm 0.7 \mathrm{~d}$ \\
\hline Green-20 mM NaCl & $1473.0 \pm 158.0 \mathrm{~b}$ & $60.1 \pm 12.4 \mathrm{a}$ & $17.5 \pm 0.4 \mathrm{a}$ & $0.4 \pm 0.0 \mathrm{a}$ & $0.1 \pm 0.0 \mathrm{a}$ & $68.9 \pm 0.6 \mathrm{e}$ \\
\hline Green-30 mM NaCl & $1235.2 \pm 52.0 \mathrm{~b}$ & $50.4 \pm 7.9 \mathrm{a}$ & $18.5 \pm 1.0 \mathrm{a}$ & $0.2 \pm 0.0 \mathrm{a}$ & $0.1 \pm 0.0$ aa & $51.9 \pm 2.7 \mathrm{~g}$ \\
\hline Red-1 mM NaCl & $2825.6 \pm 229.1 \mathrm{a}$ & $112.0 \pm 12.8 \mathrm{a}$ & $7.2 \pm 1.6 \mathrm{a}$ & $0.3 \pm 0.1 \mathrm{a}$ & $1.3 \pm 0.0$ & $86.2 \pm 1.5 \mathrm{c}$ \\
\hline Red-10 mM NaCl & $1460.1 \pm 52.2 \mathrm{~b}$ & $74.6 \pm 12.4 \mathrm{a}$ & $22.1 \pm 3.3 \mathrm{a}$ & $0.4 \pm 0.0 \mathrm{a}$ & $1.2 \pm 0.0 \mathrm{a}$ & $103.1 \pm 0.7 \mathrm{a}$ \\
\hline Red-20 mM NaCl & $1126.2 \pm 145.3 b$ & $70.1 \pm 6.4 \mathrm{a}$ & $15.5 \pm 1.5 \mathrm{a}$ & $0.3 \pm 0.1 \mathrm{a}$ & $1.1 \pm 0.1 \mathrm{a}$ & $97.0 \pm 0.3 b$ \\
\hline Red-30 mM NaCl & $1498.5 \pm 191.2 b$ & $67.5 \pm 4.9 \mathrm{a}$ & $17.4 \pm 0.5$ & $0.3 \pm 0.1 \mathrm{a}$ & $1.1 \pm 0.1 \mathrm{a}$ & $88.7 \pm 1.0 \mathrm{c}$ \\
\hline
\end{tabular}

NS,$* * * * * * *$ Nonsignificant or significant at $p \leq 0.05,0.01$, and 0.001 , respectively. Different letters within each column indicate significant differences according to Duncan's multiple-range test $(p=0.05)$. All data are expressed as mean \pm standard error, $n=3$. 
Significant genotype variation was demonstrated in terms of perilla pigmentation expressed in total chlorophyll a concentration (Table 3). When averaged over salinity treatments the highest chlorophyll a concentration was recorded in red compared to green perilla leaves (Table 3).

Sodium and chloride concentrations in the nutrient solution interfere with multiple aspects of plant biochemistry/physiology including chlorophyll biosynthesis. In the current experiment, salinity-induced degradation of chlorophyll as well as inhibition of its synthesis [37], presumably a consequence of $\mathrm{Na}^{+}$induced $\mathrm{Mg}^{2+}$ deficiency, has been driven by an extreme ratio of $\mathrm{Na}^{+} / \mathrm{Mg}^{2+}$ [38] .

Nutritional and functional properties of perilla leaves are associated with the high concentration of secondary metabolites, in particular polyphenols [1,22]. Moreover, the quantitative and qualitative variations of bioactive molecules (phenolic acids) depend on several preharvest factors, including species/genotypes, environmental conditions, developmental and physiological stage as well as the biotic and abiotic elicitors [22,38]. The major phenolic compound recorded in both green and red perilla leaves was rosmarinic acid, a caffeic acid derivate (synthesized through the phenylpropanoid pathway) representing more than $93 \%$ of the total target polyphenols determined by HPLC-DAD (Table 3). Increasing the nutrient solution salinity from 1 to $30 \mathrm{mM} \mathrm{NaCl}$ enhanced the functional quality of leaves by increasing rosmarinic acid and total polyphenol levels (Table 3). Similar beneficial effects of salinity $(30 \mathrm{mM} \mathrm{NaCl})$ on total phenolic compounds and major polyphenols (chlorogenic acid, cynarin and luteolin) of artichoke and cardoon leaves were reported previously by Colla and co-workers [24]. Elicitation effect of salinity on rosmarinic acid is very important, particularly in light of clinical and pre-clinical studies that have attributed to rosmarinic acid present in Lamiaceae species, such as perilla, widely ranging therapeutic and health-promoting (anticancer, neuroprotective, antiatherogenic, antibacterial, antiviral and antidiabetic) properties [39-42]. The application of $10 \mathrm{mM}$ $\mathrm{NaCl}$ to the nutrient solution elicited an increase in total polyphenols synthesis and accumulation in both green and red perilla compared to the non-saline control treatment, thus contributing added value to this product for human diet. Further increase of the nutrient solution salinity (20 and especially $30 \mathrm{mM} \mathrm{NaCl}$ ) however had a negative effect on total phenolics content (Table 3). A putative mechanism involved in the decrease of total polyphenols at 20 and especially $30 \mathrm{mM} \mathrm{NaCl}$ is that the antioxidant system of red and green perilla did not efficiently support reactive oxygen species (ROS) scavenging and cellular water homeostasis [22] as demonstrated by the sharp decrease in plant growth parameters and crop productivity (especially in green perilla). In addition to the positive effect of a chemical eustressor such as salinity, enhancing the production of polyphenols (rosmarinic and caffeic acids and flavonoids) by chemical elicitors such as chitosan, jasmonic acid and its ester, methyl jasmonate has been previously demonstrated effectively by several authors on culinary, medicinal and aromatic plants belonging to the family of Lamiaceae (e.g., Ocimumbasilicum and Salvia officinalis; [43-45]).

Regarding the effect of perilla genotypes, the content of sinapic acid as well as total polyphenols were 10 and 1.5-fold higher respectively in red than green perilla (Table 3). The strong effect of genetic material on target and total polyphenols has been previously demonstrated in other vegetable species such as potato [46], tomato [47], artichoke [48,49] and garlic [50]. The marked differences found between red and green perilla in terms of phenolics suggest the possibility of exploiting this quantitative variability in breeding programs aiming to select specific genotypes with fortified phytonutrient content.

\subsection{Leaf Aroma Volatile Profile}

It is well established that volatile profiles in Lamiaceae may change in relation to several interacting preharvest factors, including genotype, chemotype, cultural environment, agronomic practice, geographic location, as well as chemical elicitation agents such as jasmonic acid and chitosan [45,51-53]. This was the case in the current experiment, since the two perilla genotypes differed widely in the abundance of the two major aroma volatile components identified, perillaldehyde and perilla ketone (Table 4). Perillaldehyde (PA) constituted $41.6 \%$ of the total volatile profile in red perilla while it was not detected in the green one; on the other hand, perilla ketone (PK) was the 
most abundant (51.5\%) volatile component detected in green perilla, whereas it was non-detectable in red-pigmented perilla (Table 4). In addition to PA and PK, benzaldehyde (26.7\%) and cis-jasmone $(21.2 \%)$ were the second most abundant compounds in red- and green-pigmented perilla, respectively (Table 4). The remaining major compounds such as benzaldehyde and $\beta$-linalool detected in both cultivars were 12.7- and 1.5-fold higher in red compared to green perilla, respectively whereas an opposite trend was recorded for caryophyllene (Table 4). Durenol and thymoquinone were only detected in red perilla leaves, whereas perillene and 4-trifluoroacetylimidazole were exclusively recorded in green cultivar (Table 4 ).

The chemotype profiling revealed that Perilla frutescens var. frutescens produced exclusively perilla ketone (PK) and was classified as PK-chemotype, whereas Perilla frutescens var. crispa contained perillaldehyde (PA) instead of PK and was classified as PA-chemotype. These findings are in agreement with those of Martinetti et al. [25] who reported that open-field Japanese red and green Perilla frutescens var. crispa cultivars ('AoShiso', 'Aka Shiso', 'Qing Su' and 'Purple Zi Su') produced exclusively PA, whereas Korean green perilla (Perilla frutescens var. frutescens) contained PK. The high abundance of PA in red perilla adds nutritional value to the crop since this is the key volatile component responsible for the premium aroma and taste of perilla [15]. On the other hand, PK a terpenoid component present in green perilla leaves has been demonstrated to be toxic to animals (cattle and horses) causing pulmonary edema [9], but the effect as well as the toxic dose to humans is still equivocal [25]. Interestingly, several studies [54,55] demonstrated that PA and PK trigger the Transient Receptor Potential (TRPA1) cation channels which are actively implicated in several biological mechanisms such as the chemesthetic and trigeminal sensations, indicating perilla as a potent functional vegetable.

Upon salinization, the relative abundance of major aroma volatiles remained similar (no significant difference) to that of non-stressed plants, in both red- and green-pigmented perilla, with the exception of 1-octen-3-ol, perilla ketone, cis-jasmone and 4-trifluoroacetylimidazole (Table 4). Irrespective of perilla genotypes, treatment with $20 \mathrm{mM} \mathrm{NaCl}$ resulted in an increase in the levels of perilla ketone and 4-trifluoroacetylimidazole (Table 4). Moreover, a significant increase in the contents of 1-octen-3-ol (with 20 and $30 \mathrm{mM} \mathrm{NaCl}$ ) and cis-jasmone (in all salt-stress treatments) was observed compared to untreated plants (Table 4). Triggering the biosynthesis and accumulation of cis-jasmone could be of high interest to the cosmetic industry since this volatile component is considered an important aroma agent for perfume, fragrance as well as in aromatherapy. The increase in essential oils content and their composition under salt stress conditions has been reported previously on several species belonging to the Lamiaceae family such as Satureja hortensis, Salvia officinalis, Thymus vulgaris, Ocimum basilicum and Salvia mirzayanii [56-60]. In contrast, other studies have shown reduction or no difference in the pooled content of essential oils in lemon balm, sweet marjoram as well as basil in response to salt stress [61,62]. Conflicting reports concerning the responses of Lamiaceae species to salinity and the modulation of leaf volatile composition could be interpreted in the context of species-specific effects that may additionally depend on the magnitude of the applied stress, i.e., time of exposure and salt concentration in the nutrient solution [61]. 
Table 4. Analysis of variance and mean comparisons for the relative abundance of major aroma volatile components in green and red perilla grown under increasing $\mathrm{NaCl}$ concentration in the nutrient solution.

\begin{tabular}{|c|c|c|c|c|c|c|c|c|c|c|c|c|}
\hline \multirow[b]{2}{*}{ Source of Variance } & \multicolumn{3}{|c|}{ Aldehydes } & \multicolumn{3}{|c|}{ Alcohols } & \multicolumn{2}{|c|}{ Terpenes } & \multicolumn{2}{|c|}{ Ketones } & \multirow{2}{*}{$\begin{array}{c}\text { Diazole } \\
\text { Imidazole } \\
\text { 4-trifluoroacetyl }\end{array}$} & \multirow{2}{*}{$\begin{array}{c}\text { Quinone } \\
\text { Thymo } \\
\text { Quinone }\end{array}$} \\
\hline & 2-hexenal & Benz-aldehyde & $\begin{array}{c}\text { Perilla } \\
\text { Aldehyde }\end{array}$ & 1-octen-3-ol & Durenol & $\beta$-linalool & Perillene & Caryophyllene & Perilla Ketone & Cis-jasmone & & \\
\hline Genotype (G) & NS & $* * *$ & - & NS & - & * & - & * & - & - & - & - \\
\hline Salinity (S) & NS & NS & NS & $*$ & NS & NS & NS & NS & ** & ** & * & NS \\
\hline $\mathrm{C} \times \mathrm{S}^{\prime}$ & NS & NS & - & NS & - & NS & - & NS & - & - & - & - \\
\hline Genotype & & & & & & & & & & & & \\
\hline Green & $5.6 \pm 1.3 \mathrm{a}$ & $2.1 \pm 0.4 \mathrm{~b}$ & n.d. & $4.2 \pm 0.6 \mathrm{a}$ & n.d. & $2.8 \pm 0.2 \mathrm{~b}$ & $3.5 \pm 0.5$ & $4.7 \pm 0.2 \mathrm{a}$ & $51.5 \pm 5.2$ & $21.2 \pm 3.0$ & $4.3 \pm 0.7$ & n.d. \\
\hline $\begin{array}{l}\text { Red } \\
\text { Salinity (mM NaCl) }\end{array}$ & $7.7 \pm 1.6 \mathrm{a}$ & $26.7 \pm 3.7 \mathrm{a}$ & $41.6 \pm 2.7$ & $5.2 \pm 0.8 \mathrm{a}$ & $2.9 \pm 0.1$ & $4.0 \pm 0.5 \mathrm{a}$ & n.d. & $3.6 \pm 0.4 \mathrm{~b}$ & n.d. & n.d. & n.d. & $8.2 \pm 1.0$ \\
\hline 1 & $4.1 \pm 1.0 \mathrm{a}$ & $21.3 \pm 9.8 \mathrm{a}$ & $18.1 \pm 8.4 \mathrm{a}$ & $3.6 \pm 0.5 b$ & $1.4 \pm 0.6 \mathrm{a}$ & $2.6 \pm 0.3 \mathrm{a}$ & $2.9 \pm 1.4 \mathrm{a}$ & $4.0 \pm 0.7 \mathrm{a}$ & $21.6 \pm 9.7 b$ & $9.0 \pm 2.9 \mathrm{~b}$ & $2.8 \pm 1.4 \mathrm{ab}$ & $4.4 \pm 2.2$ \\
\hline 10 & $4.4 \pm 0.9 \mathrm{a}$ & $12.7 \pm 5.5 \mathrm{a}$ & $25.9 \pm 11.7 \mathrm{a}$ & $2.8 \pm 0.6 \mathrm{~b}$ & $1.5 \pm 0.6 \mathrm{a}$ & $2.7 \pm 0.2 \mathrm{a}$ & $1.0 \pm 0.5 \mathrm{a}$ & $3.8 \pm 0.3 \mathrm{a}$ & $38.7 \pm 17.8 \mathrm{~b}$ & $12.8 \pm 5.8 \mathrm{a}$ & $1.5 \pm 0.6 \mathrm{~b}$ & $2.5 \pm 0.0$ \\
\hline 20 & $9.8 \pm 2.5 \mathrm{a}$ & $11.5 \pm 4.3 \mathrm{a}$ & $19.8 \pm 9.0 \mathrm{a}$ & $5.9 \pm 1.2 \mathrm{a}$ & $1.4 \pm 0.6 \mathrm{a}$ & $4.2 \pm 0.7 \mathrm{a}$ & $1.5 \pm 0.7 \mathrm{a}$ & $4.9 \pm 0.6 \mathrm{a}$ & $17.9 \pm 8.2 \mathrm{a}$ & $14.9 \pm 6.7 \mathrm{a}$ & $3.1 \pm 1.4 \mathrm{a}$ & $4.9 \pm 2.3$ \\
\hline $\begin{array}{l}30 \\
G \times S\end{array}$ & $8.2 \pm 2.5 \mathrm{a}$ & $12.1 \pm 4.8 \mathrm{a}$ & $19.3 \pm 9.0 \mathrm{a}$ & $6.4 \pm 1.2 \mathrm{a}$ & $1.3 \pm 0.6$ & $4.1 \pm 0.5 \mathrm{a}$ & $1.7 \pm 0.7 \mathrm{a}$ & $4.0 \pm 0.3 \mathrm{a}$ & $24.5 \pm 11.0 \mathrm{~b}$ & $11.7 \pm 5.2 \mathrm{a}$ & $1.8 \pm 0.8 \mathrm{~b}$ & $4.6 \pm 2.1$ \\
\hline Green- $1 \mathrm{mM} \mathrm{NaCl}$ & $5.9 \pm 1.5 \mathrm{a}$ & $2.1 \pm 0.5 \mathrm{a}$ & n.d. & $3.8 \pm 1.0 \mathrm{a}$ & n.d. & $2.6 \pm 0.1 \mathrm{a}$ & $5.7 \pm 1.5$ & $5.0 \pm 0.5 \mathrm{a}$ & $43.3 \pm 1.7$ & $25.7 \pm 1.8$ & $5.7 \pm 1.6$ & n.d. \\
\hline Green-10 mM NaCl & $3.3 \pm 1.1 \mathrm{a}$ & $1.4 \pm 0.1 \mathrm{a}$ & n.d. & $2.0 \pm 0.5 \mathrm{a}$ & n.d. & $2.2 \pm 0.1 \mathrm{a}$ & $2.1 \pm 0.6$ & $3.9 \pm 0.4 \mathrm{a}$ & $77.6 \pm 9.5$ & $18.0 \pm 5.9$ & $3.6 \pm 1.3$ & n.d. \\
\hline Green-20 mM NaCl & $8.8 \pm 4.9 \mathrm{a}$ & $3.0 \pm 1.7 \mathrm{a}$ & n.d. & $4.5 \pm 1.3 \mathrm{a}$ & n.d. & $3.0 \pm 0.5 \mathrm{a}$ & $2.9 \pm 0.7$ & $5.6 \pm 0.3 \mathrm{a}$ & $35.9 \pm 3.9$ & $29.7 \pm 2.3$ & $6.3 \pm 0.5$ & n.d. \\
\hline Green-30 mM NaCl & $4.4 \pm 0.1 \mathrm{a}$ & $1.9 \pm 0.1 \mathrm{a}$ & n.d. & $6.4 \pm 1.3 \mathrm{a}$ & n.d. & $3.4 \pm 0.0 \mathrm{a}$ & $3.3 \pm 0.0$ & $4.4 \pm 0.1 \mathrm{a}$ & $49.2 \pm 0.5$ & $23.3 \pm 0.8$ & $3.6 \pm 0.1$ & n.d. \\
\hline Red-1 mM NaCl & $2.3 \pm 0.5 \mathrm{a}$ & $40.5 \pm 10.8 \mathrm{a}$ & $36.2 \pm 5.3$ & $3.4 \pm 0.4 \mathrm{a}$ & $2.9 \pm 0.1$ & $2.7 \pm 0.7 \mathrm{a}$ & n.d. & $3.0 \pm 1.1 \mathrm{a}$ & n.d. & n.d. & n.d. & $8.7 \pm 2.5$ \\
\hline Red-10 mM NaCl & $5.4 \pm 1.3 \mathrm{a}$ & $24.0 \pm 4.8 \mathrm{a}$ & $51.8 \pm 3.9$ & $3.5 \pm 0.9 \mathrm{a}$ & $3.0 \pm 0.1$ & $3.3 \pm 0.2 \mathrm{a}$ & n.d. & $3.6 \pm 0.7 \mathrm{a}$ & n.d. & n.d. & n.d. & $5.1 \pm 1.9$ \\
\hline Red- $20 \mathrm{mM} \mathrm{NaCl}$ & $10.8 \pm 2.4 \mathrm{a}$ & $20.0 \pm 4.5 \mathrm{a}$ & $39.6 \pm 3.4$ & $7.2 \pm 2.0 \mathrm{a}$ & $2.9 \pm 0.4$ & $5.3 \pm 1.1 \mathrm{a}$ & n.d. & $4.1 \pm 1.1 \mathrm{a}$ & n.d. & n.d. & n.d. & $9.9 \pm 1.8$ \\
\hline Red- $-30 \mathrm{mM} \mathrm{NaCl}$ & $12.1 \pm 4.2 \mathrm{a}$ & $22.4 \pm 3.3 \mathrm{a}$ & $38.7 \pm 6.1$ & $6.4 \pm 2.3 \mathrm{a}$ & $2.7 \pm 0.2$ & $4.8 \pm 0.8 \mathrm{a}$ & n.d. & $3.6 \pm 0.7 a$ & n.d. & n.d. & n.d. & $9.2 \pm 1.4$ \\
\hline
\end{tabular}

NS,$* * * * *$ Nonsignificant or significant at $p \leq 0.05,0.01$, and 0.001 , respectively; $\mathrm{n} . \mathrm{d}$. not detected. Different letters within each column indicate significant differences according to

Duncan's multiple-range test $(p=0.05)$. All data are expressed as mean \pm standard error, $n=3$. 


\subsection{Principal Component Analysis}

A comprehensive view of the phytochemical composition as well as the aroma volatile profile of the two perilla chemotypes in response to mild-salinity as chemical eustressor was obtained through principal component analysis (PCA). The first three principal components (PCs) were associated with eigenvalues higher than 1 and explained $87.1 \%$ of the cumulative variance, with PC1 accounting for $47.7 \%$, PC2 for $31.2 \%$ and PC3 for $8.2 \%$ (Table 5). PC1 was positively correlated with visual appearance traits $\left(\mathrm{L}^{*}\right.$ and $\left.\mathrm{b}^{*}\right)$, the two bivalent cations $\left(\mathrm{Ca}^{2+}\right.$ and $\left.\mathrm{Mg}^{2+}\right)$, and several volatile compounds (perillene, caryophyllene, perilla ketone, cis-jasmone, 4-trifluoroacetylimidazole and thymoquinone); it was negatively and strongly correlated to sinapic acid, total polyphenols, benz-aldehyde, perilla aldehyde and durenol (Table 5). PC2 was positively correlated to fresh yield, dry biomass, protein, nitrate and chlorophyll a contents and negatively associated with rosmarinic acid, 2-hexenal and 1-octen-3-ol. Moreover, the loading matrix indicates the relations among the examined qualitative variables, based on which the two vectors with an angle lower than $90^{\circ}$ are positively correlated, while an angle higher than $90^{\circ}$ means that these variables are negatively correlated. In the current study, variation in $\mathrm{Na}^{+}$concentration was most closely aligned with leaf dry matter percentage, and variation in total polyphenols was strongly correlated to perilla aldehyde (Figure 1).

Table 5. Eigenvalues, relative and cumulative proportion of total variance, and correlation coefficients for each nutritional trait with respect to the three principal components.

\begin{tabular}{|c|c|c|c|}
\hline Principal Components & PC1 & PC2 & PC3 \\
\hline Eigenvalue & 15.3 & 10.0 & 2.6 \\
\hline Percentage of variance & 47.7 & 31.2 & 8.2 \\
\hline Cumulative variance & 47.7 & 78.9 & 87.1 \\
\hline \multicolumn{4}{|l|}{ Eigen vectors $^{a}$} \\
\hline Fresh yield & 0.208 & 0.808 & 0.498 \\
\hline Shoot dry biomass & 0.383 & 0.735 & 0.505 \\
\hline $\mathrm{DM}^{\mathrm{b}}$ & 0.318 & -0.891 & 0.034 \\
\hline $\mathrm{L}^{*}$ & 0.941 & -0.310 & 0.042 \\
\hline$a^{*}$ & -0.991 & -0.019 & -0.005 \\
\hline$b^{*}$ & 0.993 & 0.012 & 0.024 \\
\hline $\mathrm{PO}_{4}{ }^{3-}$ & 0.310 & 0.843 & -0.133 \\
\hline $\mathrm{K}^{+}$ & -0.397 & 0.905 & -0.092 \\
\hline $\mathrm{Ca}^{2+}$ & 0.937 & -0.248 & -0.058 \\
\hline $\mathrm{Mg}^{2+}$ & 0.809 & 0.518 & 0.157 \\
\hline $\mathrm{SO}_{4}{ }^{2-}$ & 0.104 & -0.137 & 0.559 \\
\hline $\mathrm{Na}^{+}$ & 0.340 & -0.849 & -0.336 \\
\hline $\mathrm{Cl}^{-}$ & 0.040 & -0.924 & -0.166 \\
\hline Protein & 0.446 & 0.881 & -0.111 \\
\hline Nitrate & 0.177 & 0.916 & 0.069 \\
\hline Chlorophyll a & -0.498 & 0.783 & -0.148 \\
\hline Rosmaric acid & 0.024 & -0.689 & 0.029 \\
\hline Caffeic acid & -0.120 & 0.001 & 0.888 \\
\hline Sinapic acid & -0.993 & 0.098 & 0.040 \\
\hline Phenols & -0.872 & 0.027 & 0.202 \\
\hline 2-Hexenal & -0.268 & -0.701 & 0.629 \\
\hline Benzaldehyde & -0.917 & 0.301 & -0.130 \\
\hline Perilla aldehyde & -0.969 & 0.008 & 0.097 \\
\hline 1-Octen-3-ol & -0.272 & -0.771 & 0.067 \\
\hline Durenol & -0.993 & 0.038 & 0.074 \\
\hline$\beta$-Linalool & -0.586 & -0.0675 & 0.283 \\
\hline Perillene & 0.914 & 0.139 & 0.159 \\
\hline Caryophyllene & 0.777 & -0.302 & 0.347 \\
\hline Perilla ketone & 0.892 & 0.071 & -0.169 \\
\hline cis-Jasmone & 0.876 & -0.134 & 0.024 \\
\hline 4-trifluoroacetylimidazole & 0.868 & -0.053 & 0.164 \\
\hline Thymoquinone & -0.952 & -0.055 & 0.127 \\
\hline
\end{tabular}

a Boldface factor loadings are considered highly weighed; ${ }^{\mathrm{b}} \mathrm{DM}$, dry matter. 


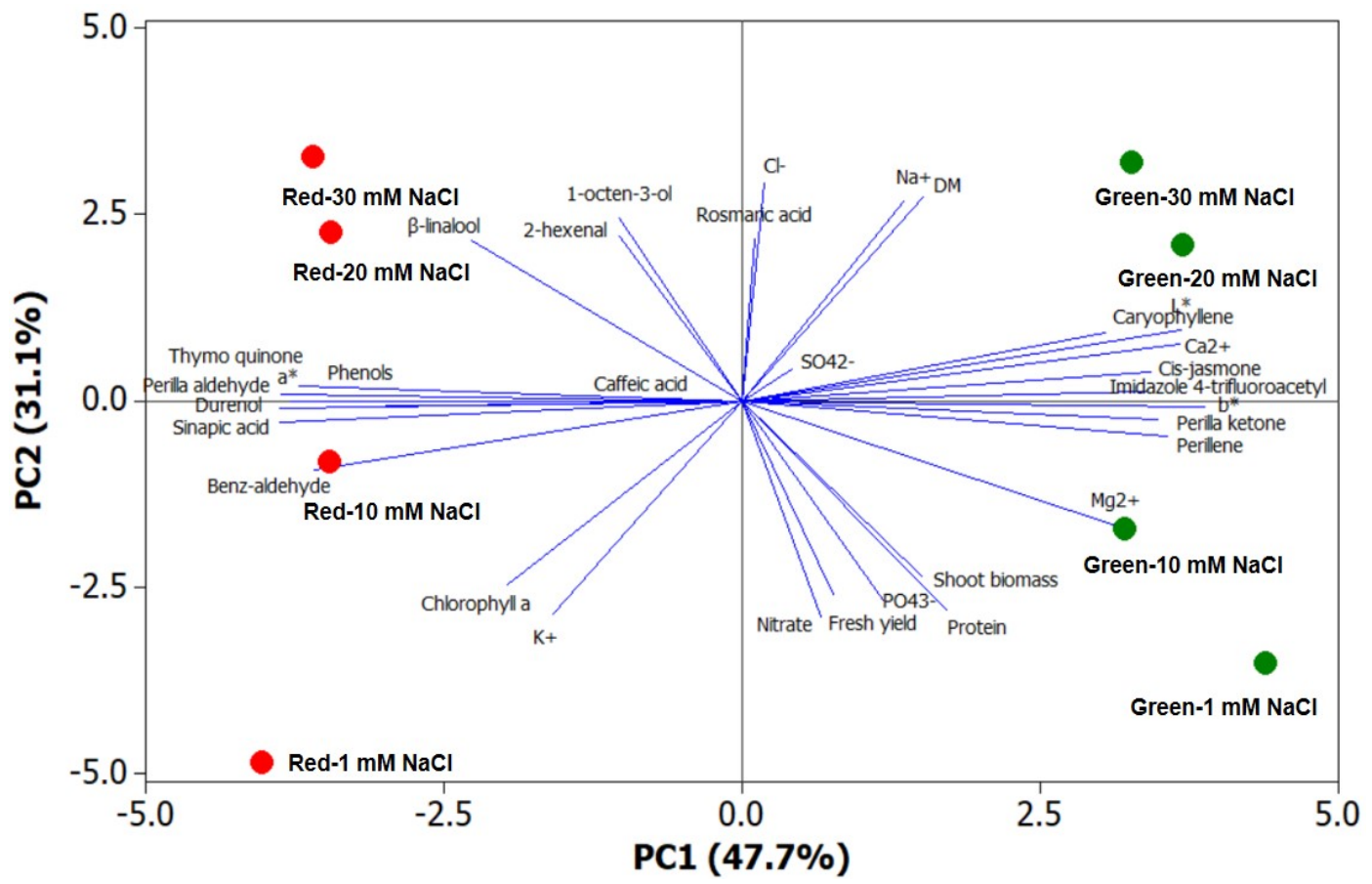

Figure 1. Principal component loading plot and scores of principal component analysis (PCA) of colorimetric data $\left(\mathrm{L}^{*}, \mathrm{a}^{*}, \mathrm{~b}^{*}\right)$, fresh yield, dry biomass, dry matter content, mineral concentrations $\left(\mathrm{NO}_{3}{ }^{-}, \mathrm{N}, \mathrm{PO}_{4}{ }^{3-}, \mathrm{K}^{+}, \mathrm{SO}_{4}{ }^{2-}, \mathrm{Ca}^{2+}, \mathrm{Mg}^{2+}, \mathrm{Na}^{+}, \mathrm{Cl}^{-}\right)$, protein and chlorophyll a contents, phenolic composition (rosmarinic, caffeic and sinapic acids), total phenolic content and aroma volatile compounds in green and red perilla grown under increasing $\mathrm{NaCl}$ concentration in the nutrient solution $(1,10,20$ or $30 \mathrm{mM} \mathrm{NaCl})$.

The efficacy of PCA for plotting species/cultivars characterization as well as its interpretive usefulness in preharvest and postharvest studies on multiple quality traits has been reported previously in a series of scientific papers $[38,63,64]$. In the current study, the score plot of the PCA superimposed on the above matrix of variables revealed strong clustering of the two perilla genotypes grown under mild to moderate salt stress conditions, with green-pigmented perilla concentrating plant growth parameters, most of the mineral composition (except the $\mathrm{K}^{+}$) and leaf colorimetry, while the red cultivar stands out for target and total polyphenols as well as several major aroma volatile components (Figure 1). Particularly, the green-pigmented perilla was positioned on the positive side of PC1 in the upper and lower right quadrants of the PCA score plot. The upper right quadrant included green cultivar treated with 20 and $30 \mathrm{mM} \mathrm{NaCl}$ that delivered leaves with high concentration of toxic ions $\left(\mathrm{Na}^{+}\right.$and $\left.\mathrm{Cl}^{-}\right)$as well as high dry matter percentage. Green perilla grown under non-saline solution or treated with $10 \mathrm{mM} \mathrm{NaCl}$ were positioned in the lower right quadrant, characterized overall by higher plant growth parameters (leaf fresh yield and shoot dry biomass), protein and $\mathrm{Mg}^{2+}$ concentration (Figure 1).

The upper left quadrant depicted treatments (red perilla treated with 20 and $30 \mathrm{mM} \mathrm{NaCl}$ ) characterized by high levels of 1-octen-3-ol, 2-hexenal and $\beta$-linalool. Finally, treatments in the lower left quadrant (red perilla at $1 \mathrm{mM}$ and especially $10 \mathrm{mM} \mathrm{NaCl}$ ) had the highest sinapic acid, total polyphenols and key volatile compounds such as perilla aldehyde (Figure 1). Altogether, the PCA outputs provide an important piece of information, namely that the targeted selection of perilla cultivar along with the application of a chemical eustressor, such as mild salt stress, could enhance the nutritional and functional quality of perilla grown in controlled environments. 


\section{Materials and Methods}

\subsection{Greenhouse Conditions and Plant Material}

A greenhouse experiment was carried out during the spring-summer growing season to examine the effect of four sodium chloride $(\mathrm{NaCl})$ concentrations in the nutrient solution on the growth, bioactive composition and aroma volatile profile of green perilla (Perilla frutescens var. frutescens; CN Seeds Ltd., Cambridgeshire, UK) and red perilla (Perilla frutescens var. crispa; CN seeds Ltd.). Seeds of both green and red perilla were germinated in vermiculite on 13 April 2015. Green and red perilla seedlings were transplanted 23 days after sowing (5 May), at the two-true-leaf phenological stage, into plastic black pots (20 cm diameter) containing $5.3 \mathrm{~L}$ of a peat/perlite in 2:1 volume ratio. Plastic pots were arranged in double rows $90 \mathrm{~cm}$ apart, and the space between plants within a row was $30 \mathrm{~cm}$. The distance between the centers of double rows was $222 \mathrm{~cm}$, resulting in a plant density of 3 plants $\cdot \mathrm{m}^{-2}$. The trial was performed at the experimental station of the Department of Agricultural Sciences, University of Naples Federico II, Bellizzi, south Italy ( $43^{\circ} 31$ N, $14^{\circ} 58$ E; $60 \mathrm{~m}$ above sea level). Perilla plants were cultivated under natural light conditions and the daily air temperature inside the glasshouse was maintained between 18 and $32{ }^{\circ} \mathrm{C}$.

\subsection{Experimental Design, Sodium Chloride Application and Nutrient Solution Management}

Eight treatments derived by a factorial combination of four $\mathrm{NaCl}$ concentrations in the nutrient solution (non salt control 1, 10, 20 or $30 \mathrm{mM}$ ) and two perilla cultivars (green and red) were delivered. The treatments were arranged in a randomized complete-block design with three replicates per treatment, amounting to a total of 24 experimental units (i.e., plots). Each experimental units (replicates) consisted of 8 plants for a total number of green and red perilla of 192 plants. The first and last plant of each experimental were considered as guards, and the biometric and chemical composition measurements were carried out on each of the six plants per experimental unit separately.

The basic nutrient solution was a modified Hoagland formulation with a mmol. $\mathrm{L}^{-1}$ composition of: $14.2 \mathrm{~N}^{-\mathrm{NO}_{3}}{ }^{-}, 1.8 \mathrm{~S}, 1.0 \mathrm{P}, 0.6 \mathrm{~N}-\mathrm{NH}_{4}{ }^{+}, 6.5 \mathrm{~K}, 4.0 \mathrm{Ca}, 2.2 \mathrm{Mg}, 1 \mathrm{Na}$, and $1 \mathrm{Cl}$ and (in $\mu \mathrm{mol} \cdot \mathrm{L}^{-1}$ ) $20 \mathrm{Fe}$, $10 \mathrm{Mn}, 0.4 \mathrm{Cu}, 1.5 \mathrm{Zn}, 20 \mathrm{~B}$, and $0.3 \mathrm{Mo}$, with an electrical conductivity (EC) of $2.0 \mathrm{dS} \cdot \mathrm{m}^{-1}$. The three saline nutrient solutions had the same basic nutrient solution plus an additional 9, 19 and $29 \mathrm{mM} \mathrm{NaCl}$, resulting in an EC of 3.0, 3.9 and $5.1 \mathrm{dS} \cdot \mathrm{m}^{-1}$, respectively. The $\mathrm{pH}$ of the four nutrient solutions was $6.0 \pm 0.3$. All nutrient solutions were prepared using deionized water. Saline treatment started on 12 May, eight days after transplanting (DAT).

The four nutrient solutions (control and three saline treatments) were pumped from independent $150 \mathrm{~L}$ tanks and delivered through a drip irrigation system through one emitter per plant at a rate of $2 \mathrm{~L} \cdot \mathrm{h}^{-1}$. Green and red perilla plants received the same solution volume, allowing for a leaching fraction of $20 \%$ to avoid any build-up of salinity in the substrate, thus maintaining the EC in the growing media at a level proximate to that of the treatment nutrient solution.

\subsection{Yield and Growth Measurements, Collection of Samples}

At the end of the greenhouse experiment (52 DAT), the final plant height as well as the number of leaves per plant were recorded on six green and red plants per replicate. The total leaf area per plant was measured using an electronic area meter (Li-Cor3000, Li-Cor, Lincoln, NE, USA). Six plants of green and red perilla per experimental unit were harvested and separated in leaves and stems. Both leaf and stem tissues were dried at $65{ }^{\circ} \mathrm{C}$ for $72 \mathrm{~h}$ until they reached a constant weight, recorded on an analytical balance (Denver Instruments, Denver, CO, USA), which corresponded to their dry biomasses. Shoot dry biomass was equal to the sum of the aerial vegetative parts (leaves + stems). Part of the dried leaf tissue was used for mineral composition. For the identification and quantification of phenolic compounds by HPLC and also for leaf volatile profiling by HS-SPME and GC/MS, fresh leaf samples from two plants per experimental plot were instantly frozen in liquid nitrogen and stored at $-80^{\circ} \mathrm{C}$ before lyophilized them in a Christ, Alpha 1-4 (Osterode, Germany) freeze drier. 


\subsection{Leaf Color Measurements}

Before harvest, leaf color was measured on the upper part of ten leaves per experimental unit plot, using an 8 mm-aperture Minolta CR-300 Chroma Meter (Minolta Camera Co., Ltd. Osaka, Japan). The Chroma meter was calibrated with a Minolta standard white plate before sampling green and red perilla leaves. The Commission internationale de l'éclairage (CIE) color space parameters recorded in the present study were lightness $\left(\mathrm{L}^{*}\right)$ and chroma components $\mathrm{a}^{*}$ and $\mathrm{b}^{*}$. $\mathrm{L}^{*}$ (ranging from $0=$ black to $100=$ white), $\mathrm{a}^{*}$ (ranging from green $[-60]$ to red $\left.[+60]\right), \mathrm{b}^{*}$ (ranging from blue $[-60]$ to yellow $\left.[+60]\right)$, and readings were transformed to those of the $\mathrm{L}, \mathrm{a}, \mathrm{b}$ color space.

\subsection{Protein and Mineral Profile Analysis}

Dried leaf tissues ground in a Wiley Mill to pass through an $841 \mu \mathrm{m}$ screen were used for protein and mineral content analysis. Total nitrogen $(\mathrm{N})$ concentration in green and red perilla tissues was determined by the Kjeldahl method following mineralization with sulphuric acid $\left(\mathrm{H}_{2} \mathrm{SO}_{4}, 96 \%\right.$, Carlo Erba Reagents, Cornaredo, Milan, Italy) in the presence of potassium sulfate and copper catalyst as described by Bremner [65] Protein content was determined following the official method 976.05 of the AOAC [66], using N-to-protein conversion factor of 6.25.

For the anions $\left(\mathrm{NO}_{3}{ }^{-}, \mathrm{PO}_{4}{ }^{3-}\right.$ and $\left.\mathrm{SO}_{4}{ }^{2-}\right)$ and cations $\left(\mathrm{K}^{+}, \mathrm{Ca}^{2+}, \mathrm{Mg}^{2+}\right.$ and $\left.\mathrm{Na}^{+}\right)$leaf analysis, $0.25 \mathrm{~g}$ of the green or red perilla dried material were suspended in $50 \mathrm{~mL}$ of ultrapure water (Milli-Q, Merck Millipore, Darmstadt, Germany) and subjected to three freeze-thaw cycles in liquid nitrogen followed by 10 min shaking in a water bath (ShakeTemp SW22, Julabo, Seelbach, Germany) at $80^{\circ} \mathrm{C}$. The mixture was centrifuged at $6000 \mathrm{rpm}$ for $10 \mathrm{~min}$ (R-10 M, Remi Elektrotechnik Limited, Valiv, India), then filtered through a $0.20 \mu \mathrm{m}$ filter paper (Whatman International Ltd., Maidstone, UK), as described previously by Rouphael et al. [67]. Anions and cations in leaf tissues were separated and quantified by ion chromatography (ICS-3000, Dionex, Sunnyvale, CA, USA) coupled to a conductivity detector. The conductivity detector with IonPac CG12A $(4 \times 250 \mathrm{~mm}$, Dionex) guard column and IonPac CS12A ( $4 \times 250 \mathrm{~mm}$, Dionex) analytical column were used for the cations analysis, while for the anions determination, an IonPac AG11-HC guard $(4 \times 50 \mathrm{~mm})$ column and IonPac AS11-HC analytical column $(4 \times 250 \mathrm{~mm})$ were employed.

\subsection{Sample Extraction and Assay Preparation}

Two hundred grams of freeze-dried leaves were extracted with $30 \mathrm{~mL}$ of methanol/water (70:30, $v / v$ ) by sonication at room temperature for $30 \mathrm{~min}$. The mixtures were centrifuged at $8000 \mathrm{rpm}$ for $5 \mathrm{~min}$ at room temperature, filtered through a $0.20 \mu \mathrm{m}$ membrane (Whatman International Ltd., Maidston, UK) and then used for HPLC analysis (phenolic compounds and chlorophyll a) and total polyphenols (colorimetric) determinations.

\subsection{Identification and Quantification of Phenolic Compounds and Chlorophyll a by HPLC-DAD}

Leaf samples of green and red perilla were filtrated through a $0.20 \mu \mathrm{m}$ membrane and analyzed by HPLC in order to quantify target phenolic compounds and chlorophyll a content, according to Kang and Lee [5]. The analysis was performed with an 1100 Series HPLC system (Agilent Technologies, Palo Alto, CA, USA) equipped with a quaternary pump (G13111A) and a diode array detector (DAD; G13114B) using a $20 \mu \mathrm{L}$ sample injection loop. A reversed phase C18 column $(150 \times 4.6 \mathrm{~mm}$ i.d., particle size $5 \mu \mathrm{m}$; Agilent Eclipse XDB-C18) was employed. The eluents were $5 \%(v / v)$ formic acid in water (eluent $A$ ) and $5 \%(v / v)$ formic acid in acetonitrile (eluent $B$ ). The gradient program was as follows: $2-7 \%$ B ( $5 \mathrm{~min}), 7-12 \%$ B (10 min), 12-17\% B (5 min), 17-25\% B (5 min), 25-35\% B (10 min) at a constant flow rate of $1.3 \mathrm{~mL} \mathrm{~min}{ }^{-1}$. Total runtime was $35 \mathrm{~min}$. Detection was performed at $320 \mathrm{~nm}$ for rosmarinic, caffeic and sinapic acids and at $666 \mathrm{~nm}$ for chlorophyll a. Identification was made by comparing retention times to rosmarinic, caffeic, sinapic and chlorophyll a standards purchased from Sigma Aldrich (Milan, Italy), by spiking samples with internal standards and by calculating their 
recovery. Calibration curves of high linearity $\left(R^{2}>0.999\right)$ were derived for each standard using five concentration levels $\left(1,10,20,50\right.$ and $\left.100 \mathrm{mg} \cdot \mathrm{L}^{-1}\right)$. All data are presented as mean \pm standard error $(n=3)$, and expressed as $\mathrm{mg} \mathrm{g}^{-1}$ dry matter. In addition, as suggested by the reviewer representative HPLC-DAD chromatograms of polyphenolic (rosmarinic, caffeic and sinapic acids) and chlorophyll a extracts of Perilla leaves monitored at $320 \mathrm{~nm}$ and $666 \mathrm{~nm}$, respectively are shown in Figure S1.

\subsection{Determination of Total Phenolics}

Total phenolics content was determined using the Folin-Ciocalteu colorimetric method with gallic acid as a standard as previously described [68]. Green and red perilla extracts (100 $\mu \mathrm{L})$ were mixed with $0.2 \mathrm{~mL}$ Folin-Ciocalteu reagent and $2 \mathrm{~mL}$ of distilled water, and incubated at room temperature for $3 \mathrm{~min}$. Total polyphenols were assayed after adding $1 \mathrm{~mL}$ of $20 \%$ sodium carbonate to the mixture and incubating for $1 \mathrm{~h}$ at room temperature. The absorbance of the resulting blue color was measured at $765 \mathrm{~nm}$ with a UV-1601PC UV-Visible scanning spectrophotometer (Shimadzu, Milan, Italy). Quantification was done with respect to the standard curve of gallic acid, and the result was expressed as mg gallic acid equivalents per $\mathrm{g}$ dry weight. Total polyphenols analysis was performed in triplicate.

\subsection{SPME-GC/MS of Volatile Compounds}

SPME-GC/MS was used for sampling and analysis of the volatile compounds in powdered green and red perilla leaves, according to Huang et al. [69] with slight modifications. A SPME holder containing a fused-silica fibre coated with a 50/30 $\mu \mathrm{m}$ layer of divinyl-benzene/carboxen/ polydimethylsiloxane (DVB/CAR/PDMS; Supelco, Bellefonte, PA, USA) was used for the absorption of the volatile compounds. Two grams of freeze-dried powdered leaves were weighed and immediately introduced into a 20-mL headspace vial. The SPME fibre was exposed in the head space of the vial for $20 \mathrm{~min}$ at $45^{\circ} \mathrm{C}$ and then introduced directly into the GC injector where the thermal desorption of the analytes was performed at $250{ }^{\circ} \mathrm{C}$ for $5 \mathrm{~min}$. An Agilent $6890 \mathrm{~N}$ GC system equipped with a 5973 mass detector (Agilent Technologies, Santa Clara, CA, USA) were used.

The analytes were separated on a $30 \mathrm{~m} \times 0.250 \mathrm{~mm}$ capillary column coated with a $0.25 \mu \mathrm{m}$ film of 5\% diphenyl 195\% dimethylpolysiloxane (HP5MS J\&W Scientific, Folsom, CA, USA) and were inserted directly into the ion source of the mass detector. Splitless injection was used for the samples. The column oven temperature was ramped at $10{ }^{\circ} \mathrm{C} \mathrm{min}-1$ from an initial temperature of 50 (held for $2 \mathrm{~min}$ ) to $150^{\circ} \mathrm{C}$, then at $15^{\circ} \mathrm{C} \cdot \mathrm{min}^{-1}$ to $300^{\circ} \mathrm{C}$, which was held for $10 \mathrm{~min}$. The injection and ion source temperatures were 250 and $230^{\circ} \mathrm{C}$, respectively. Helium (99.999\%) was used as carrier gas at a flow rate of $1 \mathrm{~mL} \mathrm{~min}{ }^{-1}$. The ionizing electron energy was $70 \mathrm{eV}$ and the mass range scanned was $40-450 \mathrm{amu}$ in full-scan acquisition mode. The volatile compounds were identified by comparing their retention indices and mass spectra with those found in the libraries NIST Atomic Spectra Database version 1.6 using a range of $85-100 \%$ similarity values. The relative amounts were calculated on the basis of peak-area ratios. Analyses of volatile compounds were also performed in triplicate. Representative SPME-GC/MS chromatogram of aroma volatile compounds of perilla leaves is reported in Figure S2.

\subsection{Statistical Analysis of Data}

Analysis of variance (two-way ANOVA) of the experimental data was performed using IBM SPSS Statistics 20 for Windows (SPSS Inc., Chicago, IL, USA). To separate treatment means within each measured parameter, Duncan's Multiple Range Test (DMRT) was performed at $p \leq 0.05$. Principal component analysis (PCA) was also conducted using Minitab 16.2.1 statistical software, aimed to extract trends when multiple qualitative variables were used by formulating new variables correlated to the original ones. Since the variables have different units of measurement, therefore those variables were standardized before conducting the PCA. The PCA outputs included treatment component scores as well as variable loading to each selected component. 


\section{Conclusions}

Genotypic variation in novel specialty crops, such as perilla along with the effective application of mild to moderate salinity eustress aimed at enhancing the bioactive content and secondary metabolites of vegetable crops constitute upcoming research areas attracting the interest of growers, consumers, nutritionists as well as food researchers. Greenhouse perilla plant performance and nutritional, functional quality and leaf aroma profiles were assessed in a bifactorial approach accounting for the effects of increasing $\mathrm{NaCl}$ concentration in the nutrient solution and genotype. Our results indicate that fresh yield, biomass production, mineral composition, target and total polyphenols and also aroma volatile composition were strongly influenced by genotype with the red-pigmented genotype exhibiting higher levels of $\mathrm{K}$, chlorophyll a, sinapic acid, total polyphenols and select aroma components (benzaldehyde and $\beta$-linalool). Our findings also demonstrated that increasing salinity in the nutrient solution suppressed plant growth parameters, especially in the green-pigmented perilla. However, the application of mild-stress $(10 \mathrm{mM} \mathrm{NaCl})$ improved functional quality aspects such as polyphenols and decreased the levels of anti-nutrients such as nitrate, whereas key aroma compounds (especially in green perilla) were improved by the application of 30 and especially $20 \mathrm{mM} \mathrm{NaCl}$ in the nutrient solution. Plant growth and the biosynthesis of bioactive molecules may be optimized according to a two-stage strategy $[70,71]$ in the application of salinity as a chemical eustressor: during the initial phenological stages plants are grown under optimal conditions, then secondary metabolism is triggered through eustress-mediated elicitation of the biosynthesis and accumulation of desired bioactive molecules.

Supplementary Materials: Supplementary Materials are available online. Figure S1. Representative HPLC-DAD chromatogram of polyphenolic (rosmarinic, caffeic and sinapic acids) and chlorophyll a extracts of perilla leaves monitored at $320 \mathrm{~nm}$ and $666 \mathrm{~nm}$, respectively; Figure S2. Representative SPME-GC/MS chromatogram of aroma volatile compounds of perilla leaves.

Author Contributions: Y.R. Defined the scientific hypothesis, set up the experimental protocol, coordinated the research and he was significantly involved in writing; P.C. Contributed in writing the introduction section and run the PCA; F.P. and R.R. Performed the whole HPLC and SPME-GC/MS analyses, and gave an important contribution on leaf aroma results interpretation; M.C.K., P.C. and M.I.S. Contributed in writing and improving the manuscript. All authors read and approved the final manuscript.

Funding: This research received no external funding.

Acknowledgments: The authors are grateful for Antonio Pannico for the statistical analysis as well as for Giampaolo Raimondi for his technical assistance in the greenhouse experiment.

Conflicts of Interest: The authors declare no conflict of interest.

\section{References}

1. Kyriacou, M.C.; Rouphael, Y. Towards a new definition of quality for fresh fruits and vegetables. Sci. Hortic. 2018, 234, 463-469. [CrossRef]

2. Butera, D.; Tesoriere, L.; Di Gaudio, F.; Bongiorno, A.; Allegra, M.; Pintaudi, A.M. Antioxidant activities of sicilian prickly pear (Opuntia ficusindica) fruit extracts and reducing properties of its betalains: betanin and indicaxanthin. J. Agric. Food Chem. 2002, 50, 6895-6901. [CrossRef] [PubMed]

3. Skowyra, M.; Falguera, V.; Azman, N.A.M.; Segovia, F.; Almajano, M.P. The Effect of Perilla frutescens extract on the oxidative stability of model food emulsions. Antioxidants 2014, 3, 38-54. [CrossRef] [PubMed]

4. Carillo, P.; Cacace, D.; De Pascale, S.; Rapacciuolo, M.; Fuggi, A. Organic vs. traditional potato powder. Food Chem. 2012, 133, 1264-1273. [CrossRef]

5. Kang, N.S.; Lee, J.H. Characterisation of phenolic phytochemicals and quality changes related to the harvest times from the leaves of Korean purple perilla (Perilla frutescens). Food Chem. 2011, 124, 556-562. [CrossRef]

6. Ghimire, B.K.; Yoo, J.H.; Yu, C.Y.; Chung, I.M. GC-MS analysis of volatile compounds of Perilla frutescens Britton var. Japonica accessions: Morphological and seasonal variability. Asian Pac. J. Trop. Med. 2017, 10, 643-651. [CrossRef]

7. Yu, H.; Kosuna, K.; Haga, M. Perilla: The Genus Perilla; Taylor and Francis: London, UK; New York, NY, USA, 2004; p. 193. 
8. Asif, M. Biological importance and health effect of Perilla frutescens. Plant. Indones. J. Pharm. 2012, $23,84-92$. [CrossRef]

9. Banno, N.; Akihisa, T.; Tokuda, H.; Yasukawa, K.; Higashihara, H.; Ukiya, M. Triterpene acids from the leaves of Perilla frutescens and their anti-inflammatory and antitumor-promoting effects. Biosci. Biotechnol. Biochem. 2004, 68, 85-90. [CrossRef]

10. Diao, Y.; Miao, Y.; Lin, X.; Liao, C.; Guo, F.; Hu, Z. Comparative analysis of five varieties in Perilla frutescens (L.) Britton by 45S rDNA FISH and 5S rDNA Sequences. Russ. J. Gen. 2009, 45, 440-444. [CrossRef]

11. Saito, K.; Yamazaki, M. Biochemistry and molecular biology of the late-stage of biosynthesis of anthocyanin: Lessons from Perilla frutescens as a model plant. New Phytol. 2002, 155, 9-23. [CrossRef]

12. Yoshida, K.; Kondo, T.; Kameda, K.; Goto, T. Structure of anthocyanins isolated from purple leaves of Perilla ocimoides L. var. crispa Benth and their isomerization by irradiation of light. Agric. Biol. Chem. 1990, 54, 1745-1751. [CrossRef]

13. Kosuna, K.; Haga, M.; Yu, H.C. Perilla: The Genus Perilla; Harwood Academic Publishers: Dallas, TX, USA, 1997.

14. Lin, L.Y.; Peng, C.C.; Wang, H.E.; Liu, Y.W.; Shen, K.H.; Chen, K.C. Active volatile constituents in Perilla frutescens essential oils and Improvement of antimicrobial and anti-Inflammatory bioactivity by fractionation. J. Essent. Oil Bear. Plants 2016, 19, 1957-1983. [CrossRef]

15. Lee, Y.J.; Yang, C.M. Seasonal changes of growth and leaf perillaldehyde in Perilla frutescens (L.). Britton. J. Taiwan Agric. Res. 2009, 58, 114-124.

16. Lu, N.; Bernardo, E.L.; Tippayadarapanich, C.; Takagaki, M.; Kagawa, N.; Yamori, W. Growth and accumulation of secondary metabolites in perilla as affected by photosynthetic photon flux density and electrical conductivity of the nutrient solution. Front. Plant Sci. 2017, 8, 708. [CrossRef] [PubMed]

17. Nishimura, T.; Ohyama, K.; Goto, E.; Inagaki, N. Concentrations of perillaldehyde, limonene, and anthocyanin of Perilla plants as affected by light quality under controlled environments. Sci. Hortic. 2009, 122, 134-137. [CrossRef]

18. Akula, R.; Ravishankar, G.A. Influence of abiotic stress signals on secondary metabolites in plants. Plant Signal. Behav. 2011, 6, 1720-1731. [CrossRef] [PubMed]

19. Lucini, L.; Borgognone, D.; Rouphael, Y.; Cardarelli, M.; Bernardi, J.; Colla, G. Mild potassium chloride stress alters the mineral composition, hormone network, and phenolic profile in artichoke leaves. Front. Plant Sci. 2016, 7, 948. [CrossRef]

20. Woodrow, P.; Ciarmiello, L.F.; Annunziata, M.G.; Pacifico, S.; Iannuzzi, F.; Mirto, A. Durum wheat seedling responses to simultaneous high light and salinity involve a fine reconfiguration of amino acids and carbohydrate metabolism. Physiol. Plant. 2017, 159, 290-312. [CrossRef]

21. Rouphael, Y.; Kyriacou, M.C.; Petropoulos, S.A.; De Pascale, S.; Colla, G. Improving vegetable quality in controlled environments. Sci. Hortic. 2018, 234, 275-289. [CrossRef]

22. Rouphael, Y.; Petropoulos, S.A.; Cardarelli, M.; Colla, G. Salinity as eustressor for enhancing quality of vegetables. Sci. Hortic. 2018, 234, 361-369. [CrossRef]

23. Petropoulos, S.A.; Levizou, E.; Ntatsi, G.; Fernandes, Â.; Petrotos, K.; Akoumianakis, K. Salinity effect on nutritional value, chemical composition and bioactive compounds content of Cichorium spinosum $\mathrm{L}$. Food Chem. 2017, 214, 129-136. [CrossRef] [PubMed]

24. Colla, G.; Rouphael, Y.; Cardarelli, M.; Svecova, E.; Rea, E.; Lucini, L. Effects of saline stress on mineral composition, phenolic acids and flavonoids in leaves of artichoke and cardoon genotypes grown in floating system. J. Sci. Food Agric. 2013, 93, 1119-1127. [CrossRef] [PubMed]

25. Martinetti, L.; Ferrante, A.; Bassoli, A.; Borgonovo, G.; Tosca, A.; Spoleto, P. Characterization of some qualitative traits in different perilla cultivars. Acta Hortic. 2012, 939, 301-308. [CrossRef]

26. Colonna, E.; Rouphael, Y.; Barbieri, G.; De Pascale, S. Nutritional quality of ten leafy vegetables harvested at two light intensities. Food Chem. 2016, 199, 702-710. [CrossRef] [PubMed]

27. Kyriacou, M.C.; Rouphael, Y.; Colla, G.; Zrenner, R.M.; Schwarz, D. Vegetable grafting: The implications of a growing agronomic imperative for vegetable fruit quality and nutritive value. Front. Plant Sci. 2017, 8, 741. [CrossRef] [PubMed]

28. Ali, M.B.; Khandaker, L.; Oba, S. Comparative study on functional components, antioxidant activity and color parameters of selected colored leafy vegetables as affected by photoperiods. J. Agric. Food Environ. 2009, 7, 392-398. 
29. McGuire, R.G. Reporting of objective color measurements. HortScience 1992, 27, 1254-1255.

30. Peiretti, P.G. Fatty acid content and chemical composition of vegetative parts of perilla (Perilla frutescens L.) after different growth lengths. Res. J. Med. Plant 2011, 5, 72-78. [CrossRef]

31. Gharibzahedi, S.M.T.; Jafari, S.M. The importance of minerals in human nutrition bioavailability, food fortification, processing effects and nanoencapsulation. Trends Food Sci. Technol. 2017, 62, 119-132. [CrossRef]

32. Levander, O.A. Fruit and vegetable contributions to dietary mineral intake in human health and disease. HortScience 1990, 25, 1486-1488.

33. Grattan, S.R.; Grieve, C.M. Salinity-mineral nutrient relations in horticultural crops. Sci. Hortic. 1999, 78, 127-157. [CrossRef]

34. Colla, G.; Kim, H.; Kyriacou, M.C.; Rouphael, Y. Nitrates in fruits and vegetables. Sci. Hortic. 2018, 237, 221-238. [CrossRef]

35. Borgognone, D.; Rouphael, Y.; Cardarelli, M.; Lucini, L.; Colla, G. Changes in biomass, mineral composition, and quality of cardoon in response to $\mathrm{NO}_{3}{ }^{-}: \mathrm{Cl}^{-}$ratio and nitrate deprivation from the nutrient solution. Front. Plant Sci. 2016, 7, 978. [CrossRef] [PubMed]

36. Touraine, B.; Clarkson, D.T.; Muller, B. Regulation of nitrate uptake at the whole plant level. In A Whole Plant Perspective on Carbon-Nitrogen Interactions; SPB Academic Publishing: The Hague, The Netherlands, 1994; pp. 11-30.

37. Colla, G.; Rouphael, Y.; Leonardi, C.; Bie, Z. Role of grafting in vegetable crops grown under saline conditions. Sci. Hortic. 2010, 127, 147-155. [CrossRef]

38. Rouphael, Y.; Bernardi, J.; Cardarelli, M.; Bernardo, L.; Kane, D.; Colla, G.; Lucini, L. Phenolic compounds and sesquiterpene lactones profile in leaves of nineteen artichoke cultivars. J. Agric. Food Chem. 2016, 64, 8540-8548. [CrossRef] [PubMed]

39. Gavarić, N.; Kovač, J.; Kretschmer, N.; Kladar, N.; Mozina, S.S.; Bucar, F. Natural products as antibacterial agents-Antibacterial potential and safety of post-distillation and waste material from Thymus vulgaris L., Lamiaceae. In Concepts, Compounds and the Alternatives of Antibacterials; InTech: London, UK, 2015; ISBN 978-953-51-2232-6.

40. Kim, G.D.; Park, Y.S.; Jin, Y.H.; Park, C.S. Production and applications of rosmarinic acid and structurally related compounds. Appl. Microbiol. Biotechnol. 2015, 99, 2083-2092. [CrossRef] [PubMed]

41. Lee, C.J.; Chen, L.J.; Chang, T.L.; Ke, W.M.; Lo, Y.F.; Wang, C.C. The correlation between skin-care effects and phytochemical contents in Lamiaceae plants. Food Chem. 2011, 124, 833-841. [CrossRef]

42. Zhu, F.; Asada, T.; Sato, A.; Koi, Y.; Nishiwaki, H.; Tamura, H. Rosmarinic acid extract for antioxidant, antiallergic, and $\alpha$-glucosidase inhibitory activities, isolated by supramolecular technique and solvent extraction from Perilla leaves. J. Agric. Food Chem. 2014, 62, 885-892. [CrossRef]

43. Kim, H.J.; Chen, F.; Wang, X.; Rajapakse, N.C. Effect of methyl jasmonate on secondary metabolites of sweet basil (Ocimumbasilicum L.). J. Agric. Food Chem. 2006, 54, 2327-2332. [CrossRef]

44. Li, Z.; Wang, X.; Chen, F.; Kim, H.J. Chemical changes and overexpressed genes in sweet basil (Ocimumbasilicum L.) upon methyl jasmonate treatment. J. Agric. Food Chem. 2007, 55, 706-713. [CrossRef]

45. Vosoughi, N.; Gomarian, M.; GhasemiPirbalouti, A.; Khaghani, S.; Malekpoor, F. Essential oil composition and total phenolic, flavonoid contents, and antioxidant activity of sage (Salvia officinalis L.) extract under chitosan application and irrigation frequencies. Ind. Crops Prod. 2018, 117, 366-374. [CrossRef]

46. Reddivari, L.; Hale, A.L.; Miller, C. Genotype, location, and year influence antioxidant activity, carotenoid content, phenolic content, and composition in specialty potatoes. J. Agric. Food Chem. 2007, 55, 8073-8079. [CrossRef]

47. Vallverdú-Queralt, A.; Medina-Remón, A.; Martínez-Huélamo, M.; Jáuregui, O.; Andres-Lacueva, C.; Lamuela-Raventos, R.M. Phenolic profile and hydrophilic antioxidant capacity as chemotaxonomic markers of tomato varieties. J. Agric. Food Chem. 2011, 59, 3994-4001. [CrossRef] [PubMed]

48. Petropoulos, S.A.; Pereira, C.; Ntatsi, G.; Danalatos, N.; Barros, L.; Ferreira, I.C.F.R. Nutritional value and chemical composition of Greek artichoke genotypes. Food Chem. 2018, 267, 296-302. [CrossRef] [PubMed]

49. Rouphael, Y.; Colla, G.; Graziani, G.; Ritieni, A.; Cardarelli, M.; De Pascale, S. Phenolic composition, antioxidant activity and mineral profile in two seed-propagated artichoke cultivars as affected by microbial inoculants and planting time. Food Chem. 2017, 234, 10-19. [CrossRef] [PubMed]

50. Petropoulos, S.; Fernandes, Â.; Barros, L.; Ciric, A.; Sokovic, M.; Ferreira, I.C.F.R. Antimicrobial and antioxidant properties of various Greek garlic genotypes. Food Chem. 2018, 245, 7-12. [CrossRef] [PubMed] 
51. Ha, T.J.; Lee, M.H.; Lee, J.H. Comparison of antioxidant activities and volatile compounds using GC/MS from leaves of Korean purple perilla (Perilla frutescens) grown in a greenhouse. Food Sci. Biotechnol. 2015, 24, 1979-1986. [CrossRef]

52. Złotek, U.; Szymanowska, U.; Karas', M.; Swieca, M. Antioxidative and antiinflammatory potential of phenolics from purple basil (Ocimumbasilicum L.) leaves induced by jasmonic, arachidonic and b-aminobutyric acid elicitation. Int. J. Food Sci. Technol. 2016, 51, 163-170. [CrossRef]

53. Złotek, U.; Michalak-Majewska, M.; Szymanowska, U. Effect of jasmonic acid elicitation on the yield, chemical composition, and antioxidant and anti-inflammatory properties of essential oil of lettuce leaf basil (Ocimumbasilicum L.). Food Chem. 2016, 213, 1-7. [CrossRef]

54. Bassoli, A.; Borgonovo, G.; Caimi, S.; Scaglioni, L.; Morini, G.; Schiano Moriello, A.; Di Marzo, V.; De Petrocellis, L. Taste-guided identification of high potency TRPA1 agonists from Perilla frutescens. J. Bioorg. Med. Chem. 2009, 17, 1636-1639. [CrossRef]

55. Laureati, M.; Buratti, S.; Bassoli, A.; Borgonovo, G.; Pagliarini, E. Discrimination and characterisation of three cultivars of Perilla frutescens by means of sensory descriptors and electronic nose and tongue analysis. Food Res. Int. 2010, 43, 959-964. [CrossRef]

56. Baatour, O.; Kaddour, R.; AidiWannes, W.; Lachaal, L.; Marzouk, B. Salt effects on the growth, mineral nutrition, essential oil yield and composition of marjoram (Origanummajorana). Acta Physiol. Plant. 2010, 32, 45-51. [CrossRef]

57. Baher, Z.F.; Mirza, M.; Ghorbanli, M.; Rezaii, M.B. The influence of water stress on plant height, herbal and essential oil yield and composition in Saturejahortensis L. Flavour. Fragr. J. 2002, 17, 275-277. [CrossRef]

58. EzzEl-Din, A.A.; Aziz, E.E.; Hendawy, S.F.; Omer, E.A. Response of Thymus vulgaris L. to salt stress and alar (B9) in newly reclaimed soil. J. Appl. Sci. Res. 2009, 5, 2165-2170.

59. Hendawy, S.F.; Khalid, K.A. Response of sage (Salvia officinalis L.) plantstozinc application under different salinity levels. J. Appl. Sci. Res. 2005, 1, 47-155.

60. Valifard, M.; Mohsenzadeh, S.; Kholdebarin, B.; Rowshan, V. Effects of salt stress on volatile compounds, total phenolic content and antioxidant activities of Salvia mirzayanii. S. Afr. J. Bot. 2014, 93, 92-97. [CrossRef]

61. Barbieri, G.; Vallone, S.; Orsini, F.; Paradiso, R.; De Pascale, S.; Negre-Zakharov, F.; Maggio, A. Stomatal density and metabolic determinants mediate salt stress adaptation and water use efficiency in basil (Ocimumbasilicum L.). J. Plant Physiol. 2012, 169, 1737-1746. [CrossRef]

62. Shalan, M.N.; Abdel-Latif, T.A.T.; Ghadban, E.A. Effect of water salinity and some nutritional compounds of the growth and production of sweet marjoram plants (Marjoranahortensis L.). Egypt. J. Agric. Res. 2006, $84,959$.

63. Kyriacou, M.C.; Soteriou, G.A.; Rouphael, Y.; Siomos, A.S.; Gerasopoulos, D. Configuration of watermelon fruit quality in response to rootstock-mediated harvest maturity and postharvest storage. J. Sci. Food Agric. 2016, 96, 2400-2409. [CrossRef]

64. Rouphael, Y.; Giordano, M.; Cardarelli, M.; Cozzolino, E.; Mori, M.; Kyriacou, M.C.; Bonini, P.; Colla, G. Plantand seaweed-based extracts increase yield but differentially modulate nutritional quality of greenhouse spinach through biostimulant action. Agronomy 2018, 8, 126. [CrossRef]

65. Bremner, J.M. Total Nitrogen 1. In Methods of Soil Analysis; Black, C.A., Evans, D.D., White, I.L., Ensminger, L.E., Eds.; American Society of Agronomy: Madison, WI, USA, 1965; pp. 1149-1178.

66. AOAC. Official Method of Analysis, 18th ed.; Association of Official Analytical Chemists: Washington, DC, USA, 2005.

67. Rouphael, Y.; Colla, G.; Giordano, M.; El-Nakhel, C.; Kyriacou, M.C.; De Pascale, S. Foliar applications of a legume-derived protein hydrolysate elicit dose-dependent increases of growth, leaf mineral composition, yield and fruit quality in two greenhouse tomato cultivars. Sci. Hortic. 2017, 226, 353-360. [CrossRef]

68. Gallo, M.; Ferracane, R.; Graziani, G.; Ritieni, A.; Fogliano, V. Microwave assisted extraction of phenolic compounds from four different spices. Molecules 2010, 15, 6365-6374. [CrossRef] [PubMed]

69. Huang, B.; Lei, Y.; Tang, Y.; Zhang, J.; Qin, L.; Liu, J. Comparison of HS-SPME with hydrodistillation and SFE for the analysis of the volatile compounds of Zisu and Baisu, two varietal species of Perilla frutescens of Chinese origin. Food Chem. 2011, 125, 268-275. [CrossRef] 
70. Murthy, H.N.; Lee, E.J.; Paek, K.Y. Production of secondary metabolites from cell and organ cultures: Strategies and approaches for biomass improvement and metabolite accumulation. Plant Cell Tissue Organ Cult. 2014, 118, 1-16. [CrossRef]

71. Trivellini, A.; Lucchesini, M.; Maggini, R.; Mosadegh, H.; Sulca Villamarin, T.S.; Vernieri, P.; Mensuali-Sodi, A.; Pardossi, A. Lamiaceae phenols as multifaceted compounds: Bioactivity, industrial prospects and role of "positive-stress". Ind. Crops Prod. 2016, 83, 241-254. [CrossRef] 